\title{
Everything but the Squeal: The Politics of Porcinity in the Livre des Propriétés des Choses
}

\section{Sven Gins (D)}

check for updates

Citation: Gins, Sven. 2021.

Everything but the Squeal: The

Politics of Porcinity in the Livre des

Propriétés des Choses. Religions 12: 260.

https://doi.org/10.3390/rel12040260

Academic Editor: David J. Bryant

Received: 16 February 2021

Accepted: 30 March 2021

Published: 8 April 2021

Publisher's Note: MDPI stays neutral with regard to jurisdictional claims in published maps and institutional affiliations.

Copyright: (c) 2021 by the author. Licensee MDPI, Basel, Switzerland. This article is an open access article distributed under the terms and conditions of the Creative Commons Attribution (CC BY) license (https:// creativecommons.org/licenses/by/ $4.0 /)$.
Faculty of Arts, University of Groningen, 9712 EK Groningen, The Netherlands; s.gins@rug.nl

\begin{abstract}
Mediaeval encyclopaedias described nonhuman animals in terms of their corporeality and cosmic significance by combining zoological and theological knowledge. Such descriptions were therefore prescriptions of normative parameters for how animals were supposed to function within Christian society, rather than objective observations. As mediaeval conceptualisations of species were highly malleable, particular animals that shared no biological relation could be considered kin, and animals who behaved against their prescribed nature could become a different animal altogether. This paper investigates how several species were implicated in the mediaeval invention of what it meant to be (like) a pig. My counter-hegemonic reading of the Livre des propriétés des choses, a fifteenth-century French encyclopaedia, draws attention to how late mediaeval Christian scripts of porcinity simultaneously defined the nonhumanity of pigs and of 'other' humans. These render the idea of the pig inseparable from what it meant to be human. I contend that the Livre des propriétés des choses employs discourses of porcinity to self-define and -stabilise particular notions of human identity by debasing and othering human and nonhuman animals with seemingly porcine traits. Additionally, I underline how such fabrications of humanity are often mired in practices that devaluate and harm real animals, including other humans. Mediaeval studies need to further address the crucial roles of animal suffering in human history. This way, historians can add valuable insights to present debates about anthropocentrism and its devastating socio-ecological consequences.
\end{abstract}

Keywords: religion; anthropocentrism; (nonhuman) animals; history of Christian thought; historical anthropology; human-animal studies; critical animal studies

"Knowledge, which is power, knows no limits, either in its enslavement of creation or in its deference to worldly matters ... . What human beings seek to learn from nature is how to use it to dominate wholly both it and human beings"

(Adorno and Horkheimer [1947] 2002, p. 2)

\section{Introduction}

History is the lifeblood of all animals; we are incomplete without it. ${ }^{1}$ Its ever-evolving abundance of artefacts and stories reveals our roots, shapes our notions of self, and teases us with a glimpse of what we could become. According to some scholars, members of Homo sapiens are, by their very nature, 'incomplete' animals that require cultural artifices to survive and to achieve humanity (Geertz [1966] 1973; Grene 1974). Consequently, humans ceaselessly engage in anthropopoiesis: (re-)defining what it means to be human. Anthropopoiesis operates via narratives and rituals which unravel how a particular idea of humanity is modelled while striving to legitimise why that very model of humanity is the only valid one (Calame and Kilani 1998, p. 7). As perpetually (re)inventing our own

1 I subscribe to the idea that humans are animals, so I invoke 'animals' as a category that encompasses all fauna-including humans. Some studies insist on the use of 'human animals' to underline this, but I find this unhelpful to work with so I will maintain the term 'humans'. Likewise, I will refer to nonhuman animals as 'nonhumans'. The extremity of a human-nonhuman distinction facilitates bringing "buried assumptions into the full light of consciousness, thus inspiring articulate contradiction" (Ritvo 2007, p. 119). 
humanity can feel like an onerous chore, anthropopoiesis inevitably relies on 'others': individuals, communities, divinities, and nonhumans (Remotti 1998, pp. 27-28). ${ }^{2}$ Nonhumans constitute a particularly rich resource for human self-definition as their variety can reflect the diverse ambit of humanity (Cohen 1994).

Moreover, drawing clear-cut barriers between Us (humans) and Others (nonhumans) reassures us that Culture and Nature differ while offering the illusory power to critique forms in which the social sphere naturalises (Rivera 1998, p. 51). An example of this is the humanist model, which imagines humans as rational animals endowed with language (Braidotti 2013a, p. 1). Going back at least to Protagoras, this idea has found a particularly salient expression in Leonardo da Vinci's Vitruvian Man, an idealised embodiment of human perfection that symbolises a specific set of mental, discursive, and spiritual values that humankind should actualise. Yet, the humanist model is in fact "deeply male-centred and Eurocentric", its fragile identity grounded in binary logics of exclusion which organise perceived differences "on a hierarchical scale of decreasing worth" (Braidotti 2013a, p. 2). The more one differs from the Vitruvian norm-i.e., pristinely white, male, able-bodiedthe more 'other' - i.e., inferior, undesirable, and disposable—one is. The humanist model is therefore inherently founded on human exceptionalism as it only maintains felicity by insisting on the inferiority and irrationality of other, nonhuman species. For instance, mediaeval exemplum literature such as the fourteenth-century Ci nous dit asserts that children must 'lose the way of beasts' to attain adult humanity (Dittmar et al. 2011, p. 27). ${ }^{3}$ Such a "discourse of animality" (Wolfe 2003, p. xx) not only demeans nonhumans by assuming that they are ontologically inferior to humans, but it also legitimises the erroneous notion that not all humans are inherently equal. Indeed, the allegation that subaltern humans are kinspeople of so-called lesser species has long been an insidious strategy to justify their violation and oppression (Cohen 2008, pp. 42,48). The domination and objectification of nonhumans has thus also provided a model for the reification, hierarchisation, and subjugation of humans, past and present (Rivera 1998, p. 56).

Perceptions of biological kinship have not remained static. Modern biology considers chimpanzees and bonobos the closest evolutionary relatives of humankind because of their shared 98.7\% genomic similarity to humans (Waterson et al. 2005, p. 71; Prüfer et al. 2021, p. 527). Yet, from a historical perspective, this biological kinship has achieved consensus only recently, resulting from debates popularised by Charles Darwin, who wrote about the "ape-like progenitors" of primeval humans (Darwin 1871, pp. 85-86; passim). In Western medicine, this displaced the domestic pig, Sus scrofa domesticus, from her long-maintained position as humankind's closest nonhuman relative. Prior to the Enlightenment, pigs' uncanny anatomical resemblance to humans ensured that mediaeval Christian medicine-which inherited much from Greek and Arabic medicine- taught that pigs resembled human anatomy more than any other nonhuman species. In fact, students of medicine were schooled in human anatomy through the dissection of domestic pigs at least up to the fourteenth century, a fact that doctors did not declare too openly because of the assumed spiritual impurity of pigs (Pastoureau 2011a, p. 61). ${ }^{4}$

Despite a recent surge of interest in the 'animal turn' of the humanities, the study of nonhuman histories remains peripheral to mediaeval history (Taylor 2018, p. 2). Nonhuman species such as pigs surface in socioeconomic studies, which generally represent them as animate objects-pawns in the history of human welfare creation (Van Molle 2012,

2 These 'others' are not necessarily directly involved in the anthropopoietic process; nonhumans may be abstracted into symbolic or metaphoric vehicles that articulate human identity. For instance, as sacred intermediaries of divine entities (e.g., God's Leviathan) or as didactive examples like Aesop's fables (Rivera 1998, pp. 58-59).

3 For a compelling study into mediaeval notions of children 'becoming' human, see Mitchell (2014). An exemplum (Latin for 'example') is a rhetorical device that illustrates a moral point in narrative and/or visual form. Exempla are didactive tools, devised with the intention to stimulate others to adopt the deviser's moral framework and emulate virtuous behaviour. The Middle Ages have a particularly rich literary history of exempla.

4 This usage of domestic pig bodies was so common that anatomical schools such as the one at Montpellier managed to dissect over 500 pigs annually in the early fourteenth century (Pastoureau 2011b, p. 122). 
p. 471). ${ }^{5}$ Cultural and religious studies mainly investigate the symbolic economy of nonhumans as, for instance, human property, vehicles of human self-expression, allegorical surrogates for people or human morals (Thomas 1983; Salisbury [1994] 2011; Flores 1996; Cohen 2008). The nonhuman itself is rarely what animates these discussions (Taylor 2018, p. 3). Yet, life finds a way to expand to new territories. This is the case in Critical Animal Studies (CAS), a field that has gained considerable impetus in recent years. CAS strives for new forms of animal liberation through a focus on nonhumans that decentres the anthropos. Scholars raise ethical implications for how humans treat nonhumans by casting light on nonhumans' agency, as well as their interactions, entanglement, and coevolution with humans. CAS has also begun to flourish in mediaeval studies, demonstrating how mediaeval encounters between humans and nonhumans of all kinds underline the inherent instability of the hierarchical human/animal dichotomy (e.g., Steel 2011, 2019; Baratay 2012; Crane 2013; Kay 2017; McCracken 2017; Erwin 2018; Warren 2018). ${ }^{6}$ This growing body of work illustrates that mediaeval history is not just our own; it is inextricably bound, stitched, and glued together with nonhuman lives, revealing the ethical urgency of mediaevalists critical engagement with nonhuman histories. ${ }^{7}$

Great strides have been taken to deliver mediaeval pigs from their confinement in the so-called little history of "futile, anecdotal, or marginal" topics and write their proper history (Pastoureau 1999, p. 13). Scholars have examined the physiognomy of mediaeval domestic pigs in iconography (Meyer 2006; Philips 2007; Pastoureau 2011b; Steel 2011). ${ }^{8}$ In a recent study, Jørgensen (2018) argues that the focus on practical symbolism in high mediaeval depictions of pig slaughter gave way in the Late Middle Ages to images wherein pigs' blood is a key component that alludes to the sacrificial dimension and spiritual connotations of pig slaughter. Pigs had tremendous importance within mediaeval Christian cuisine as pork was the meat par excellence for Christians (Fabre-Vassas 1997; Pastoureau 2012; Rogers 2012; Jørgensen 2018). According to Pastoureau (1987a), the scarcity of osteological evidence for pig meat's dietary primacy can be explained by the fact that, unlike other animals kept as livestock, from pigs "everything, absolutely everything was used" (p. 17) - except their squeals. ${ }^{9}$ Mediaeval pig rearing and slaughter were practices fraught with insoluble tensions, however. Fabre-Vassas (1997) observes that the domestic pig, though an opportunistic omnivore, was "treated like a vegetarian, an adult nourished like a toothless baby, a table companion who is kept yet feared for his potential savagery" (p. 3). Since domestic pigs were so difficult to manage it is unsurprising that the fourteenth-century poet Eustache Deschamps for instance dedicated a ballad to the festive occasion of a pig's slaughter; "its refrain, 'Pourcel ne fist bien en sa vie' (a pig does no good in its life), might be paraphrased as 'the only good pig is a dead pig.'" (Steel 2011, p. 180). ${ }^{10}$ Moreover, pigs' ambivalent reputation ensured that the humans who reared or

5 Notable examples of works that steer this field in new directions are Aleksander Pluskowski's edited collection, Breaking and Shaping Beastly Bodies: Animals as Material Culture in the Middle Ages (Pluskowski 2007), and Kreiner (2017) study of pigs' influence on Merovingian economic culture and administration.

6 Additionally, multiple journals have published article clusters and special issues on the intersection of CAS and mediaeval studies, e.g., New Medieval Literatures (Crane 2010); Postmedieval (Steel and McCracken 2011); Studies in the Age of Chaucer (Rudd 2012); Enarratio (Goodrich and Figg 2013). Several publishers also have dedicated anthologies to the subject, e.g., 'Palgrave Studies in Animals and Literature' and Routledge's 'Perspectives on the Non-Human in Literature and Culture'.

7 This is no metaphor: the majority of sources that mediaevalists work with are quite literally no more than stains on nonhuman body parts (Holsinger 2009; Kay 2017).

8 At this point, I feel I must state how restrictive I find the English nomenclature for these so-called wild boars. The fact that one must insist on their supposed wildness-if only to be clear about which kind of male pig one refers to- troubles me as it assigns a pejorative connotation to the absence of (direct) human influence in the lives of these animals. I am confounded that there is no more neutral term in English available like there is in French (senglier), Dutch (everzwijn), or German (Eber), for instance. Therefore, in hopes of somewhat removing the trappings of the standard English denomination, I will henceforth refer to wild pigs as 'undomesticated pigs' (admittedly this term is also not without problems) or as 'boars' (gender-neutral-unless specified otherwise).

9 For example, Buren (1987) discusses the plethora of culinary uses for pigs, past and present, at length.

10 Kearney (1991) disagrees with the adage that the only good pig is a dead pig, yet all of the 'good' features of living pigs that he lists (pp. 95-98) relate to pigs' use value to humans-farmers in particular. 
slaughtered them, viz. swineherds and butchers, were also regarded with fear, loathing, or suspicion (Steel 2011; Pastoureau 2012).

Scholars have copiously examined the symbolic force of pigs in mediaeval Christianity. According to Milo Kearney (Kearney 1991; echoed in Pastoureau 2011b, p. 119), Christian moralisation ensured that the fertility, excess, and assertiveness of pigs, celebrated by pagan and Graeco-Roman cultures, came to be perceived as lasciviousness, gluttony, and aggression in the mediaeval West. These-by the Late Middle Ages-common negative associations with sinfulness and all things diabolical have received extensive attention (Schouwink 1984; Pastoureau 1987a, 1987b, 2011b, 2012; Jones 1991; Cohen 1992, 1994; Cohen 2008, pp. 220-21). ${ }^{11}$ The pigs that belonged to the Hospital Brothers of Saint Anthony, patron saint of pigs and swineherds, constituted a rare positively associated exception, however (Fabre-Vassas 1997). These pigs, whose lard was used to cure the sick and feed the poor, were given free rein to wander the streets (Pastoureau 1987b, 2011b, 2012; Steel 2011). To make them recognisable, Antonine pigs wore a little bell that also had an apotropaic function: warding off the infamous 'Saint Anthony's Fire', an umbrella term for all kinds of skin conditions and diseases in humans and nonhumans (Fabre-Vassas 1997; Van Uytven 2003). Even so, the pig that accompanied St. Anthony depictions often did not signify this beneficial idea, instead it embodied the sins of gluttony and lust and diabolical attacks that Anthony faced and overcame during his spiritual seclusion in the desert (Cohen 2008, p. 221). Their overall rather negative reputation and their anatomical similarity to humans could explain that, of all prosecuted nonhumans in the legal courts of premodern Europe, pigs were "the star of this judiciary bestiary" (Pastoureau 2012, p. 206). ${ }^{12}$ Some scholars argue that the upside-down hanging of pigs in late mediaeval Burgundy parallels the inverted hangings of Jews and that these executions humanised pigs and animalised Jews (Fabre-Vassas 1997; Enders 2002). ${ }^{13}$

Mediaeval Christianity's dehumanisation and persecution of human 'others' often involved pigs and pork, as exemplified by Islamophobic (Constable 2013; Heng 2018, pp. 117-18; Dursteler 2020; Van Es 2020, pp. 11-12) and particularly antisemitic practices (Cohen 1992; Enders 2002; Strickland 2007; Steel 2011; Pareles 2015). ${ }^{14}$ According to Fabre-Vassas (1997), the pig represented a temporal passage from 'primitive' Judaism to 'young' Christianity and Christians saw the Jewish avoidance of pork consumption as admission of a "secret, because incestuous, appetite" for their swine 'kin' (p. 325). Pareles (2019) proposes the concept "already/never" to designate how temporal abjection foreclosed any possibility of Jewish conversion: Jews could never truly become Christian because they were deemed so essentially porcine as to be beyond redemption. Pareles' study builds on Steel (2011) crucial insight that mediaeval Christians equated Muslims and Jews, because they refused to eat pork, with pork itself, thus excluding these people from the supposedly exceptional category of the human and relegating them to the nonhuman category of pigs, a category that necessitated human subjugation because of its inherent resistance to containment. Christian modes of dehumanisation did not only target religious opponents, however. Pigs were also utilised as a rhetorical device in political polemics (e.g., Keen 2007, pp. 114-15) and for the humiliation of disabled people. For instance, Pastoureau (2012, p. 204) observes that pigs' limited visual acuity made them henchmen of the devil, just like other creatures that largely lived in darkness, such as cats, foxes, and blind people. This association between pigs, visual impairment, and godlessness materialised in an especially disturbing form through popular late mediaeval urban spectacles. 'The

11 I consider these negative associations more in-depth throughout this article.

12 The prevalence of pigs in these so-called animal trials has been studied particularly extensively by Pastoureau $(1993,1999,2000,2012)$ and Esther Cohen (1986, 1992, 1994).

13 These arguments are largely based on the popular misconception that an infanticidal sow of Falaise was dressed up like a human and hanged upside down at the public gallows in 1386. While a sow was indeed executed through inverted hanging in Falaise at the time, she was decidedly not dressed up in human attire for the occasion. The misconception stems from misrepresentation in eighteenth- and nineteenth-century studies, each scholar rendering the story more sensational than the last. For an excellent genealogy of this historiographical myth, see Friedland (2012, pp. 2-11) and Dubois (2017).

14 I realise that 'Islamophobia' is a modern term; for lack of a better word, I use it here to refer to the social, religious, and political marginalisation of Muslims. 
game of the blind and the pig' tasked blind mendicants with hitting a pig to death, yet in practice, the blind participants mostly struck each other, much to the amusement of spectators (Wheatley 2002). Richard (2015) argues that this game provided an exemplum of humankind's struggle with sin while equating blind people to pigs-as both were perceived as visually impaired, filthy, and omnivorous gluttons.

Domestic pigs, both in their flesh-and-blood reality and ideated form, thus occupied a complicated position in the Christian Middle Ages. Their multivalent, close interrelation with other species was evident from the fact that, for instance, domestic pigs and boars differed only in degrees in exegesis and natural history (Schouwink 1984; Fabre-Vassas 1997; Meyer 2006; Steel 2011; Pastoureau 2012; Lutwyche 2019). Indeed, by the Late Middle Ages, "the symbolic frontier between the domestic pig and the wild pig is no longer impermeable". ${ }^{15}$ Yet, pigs' anatomical similarity and everyday proximity to humans as well as their symbolic force also had myriad applications to human 'others', leading Fabre-Vassas (1997) to propose that pigs were "maintained at the boundary between man and animal" (p. 5). Positioning pigs so squarely in the middle of this binary humannonhuman divide seems overly simplistic to me, however, as this 'privileged' position of pigs suggests that they were sufficiently different to merit an entirely separate position from other species in Christian society. I maintain that pigs were decidedly perceived as nonhuman 'others' in mediaeval Christianity, yet their uncanny proximity to humans also made them suspect and ensured their infamy: here was an Other that called into question humankind's sense of unicity, refinement, and superiority. To legitimise human exceptionalism, species boundaries were continuously clearly defined and reasserted. Porcine animals had to be rendered utterly inferior, resulting in their objectifying instrumentalisation by humans. ${ }^{16}$

My usage of 'porcine animals' is deliberate as I want to highlight the close interlinkage, in mediaeval Christian thought, of domestic pigs with many kinds of other species. ${ }^{17}$ Mediaeval conceptualisations of species were relatively fluid: a species was generally understood to be a 'kind' or a sort of things (Wilkins 2009, p. 38). This mode of thought allowed association between animals that modern biology presently separates into subspecies from the same species, such as domestic pigs and European wild boars, or classifies into altogether different taxonomic orders, as is the case with pigs (Artylodactila), porcupines (Rodentia), hedgehogs (Eulipotyphla), porpoises (Cetacea), and humans (Primates). ${ }^{18}$ Thus, while the mediaeval domestic pig was recognised as a particular kind of creature, it was also perceived to constitute part of a larger constellation of animal species, interlinked by the porcine traits they seemingly shared, a notion that has hitherto received comparatively little attention. I propose that pigs' multivalent potential for cross-species interconnection generated-what I coin-'porcinity', a fluid container of allegedly porcine traits. ${ }^{19}$ Porcinity allowed pigs to discursively travel, as it were, and implicate diverse species in the making of what it meant to be human and what it meant to be (like) a pig. I argue that late mediaeval French encyclopaedias utilised discourses of porcinity to self-define and

15 (Pastoureau 2011b, p. 69): “Les savoirs et les sensibilités du haut Moyen Âge ne confondaient pas les deux animaux; désormais, entre le cochon domestique et le cochon sauvage la frontière symbolique n'est plus impermeable".

16 When I speak of 'porcine' animals, I refer to any animal that was supposed to have pig-like features (regardless of whether or not the animal is biologically related to pigs). 'Suine' animals denotes animals which biology presently classifies in the Suidae family, for instance domestic pigs and boars.

17 Although mediaeval Christian writers were unfamiliar with the biological concept of species-a notion that only started being developed by the end of the sixteenth century - they were well acquainted with species as a vernacular and logical term that could be applied to the classification of animals (Wilkins 2009, pp. 231-32).

18 Though it has been a point of debate whether domestic pigs are a different species altogether than wild boars, there currently appears to be a consensus that they are both subspecies of Sus scrofa as both kinds of pigs can reproduce with one another. The zooarchaeologists Frantz et al. (2015) argue that domestic pigs continued to mate with boars long after humans domesticated them.

19 Pareles (2019) has shown how particular models of conversion could invoke the porcine "as a (temporally) infinite container for the Jewish" and how, vice versa, Judaism could be "a perpetual container for the porcine" (p. 241). I see porcinity as a kind of 'omnivorous' container, in which these conversion models could have a place, along with all kinds of other notions about porcine identity. Because of this omnivory, porcinity has a profound capacity for 'banality', meaning that porcinity can also be invoked unconsciously, unwittingly, and with little or no intention to refer to actual pigs. This usage of 'banality' is inspired by Elliot (2017) definition of 'banal medievalisms' (p. 36). 
-stabilise particular notions of human identity by debasing and othering ostensibly porcine animals, both human and nonhuman, often with devastating consequences.

These objectives are operationalised through a close reading of the Livre des propriétés des choses ('Book of the properties of things', henceforth ' $L D P$ '). This Middle French translation of Bartholomaeus Anglicus' famous encyclopaedia, the Liber de proprietatibus rerum (c. 1245), was completed in 1372 by the Augustinian hermit Jean Corbechon by order of king Charles V. Both the Latin original and the French version consist of 19 thematic books that jointly seek to explain the nature of God's universe in order to render divine creation intelligible to Christian readers. However, Corbechon's work is not to be considered a simple French analogue but rather a "veritable work of adaptation" (Ducos 2014, p. 10). In lieu of drastically altering the thirteenth-century content of the original with more novel or accurate insights, Corbechon's objective lay in the popularisation of its knowledge, rendering the meaning of the scholarly original accessible to a wider audience-in particular the relatively educated laypeople at the royal French court. ${ }^{20}$ Like other contemporary encyclopaedias, Corbechon's prologue was written in a mirrors for princes style, underlining the ideal monarch's innate desire for a discernment that coupled wisdom with competence (Ribémont 1999; Veysseyre 2008).

A prime reason for the $L D P^{\prime}$ s significance is because of Corbechon's profound attention to the meaning of words, including common vocabulary, favouring paraphrase over the use of potentially confusing terminology. For instance, Corbechon was reticent to copy the Latin term animal (denoting any living creature, be it human or nonhuman) - which from the twelfth century onwards, took on the specialised meaning of an "animate being deprived of reason (as opposed to humankind)"-instead, translating it as hommes et les bestes ('humans and beasts') or a similar distinction (Veysseyre 2008, p. 336). Corbechon also tinkered with Bartholomaeus' etymologies to connect them more clearly to understandable French terms, sometimes adding more in-depth explanation or directly citing Bartholomaeus' sources, other times omitting particular etymologies, or in some cases even inventing new etymologies of his own (Ribémont 1999, pp. 35-37). For example, Corbechon etymologically connected the porcupine with the pig (cf. infra), a link that Bartholomaeus did not (need to) make because the Latin term for porcupine is herinacius, which had no porcine connotations.

The success of the French translation was considerable: many private fifteenth-century manuscript libraries possessed a copy and over 45 of these manuscripts have survived the wreck of time (Byrne 1981; Ribémont 1999). ${ }^{21}$ Moreover, with the release of ten editions by 1500, the LDP was "one of the most popular of early printed books" (Byrne 1981, p. 99). Furthermore, the French translation constituted the basis of several other vernacular translations, demonstrating the far-reaching mediaeval interest in rationalising the natural world within a Christian framework (Ribémont 1999, pp. 33-35; Keen 2007, pp. 103-25). ${ }^{22}$ My analysis relies on two late-fifteenth-century manuscripts from the Bibliothèque nationale de France (BnF), mainly MS fr. 9140 and, to lesser extent, MS fr. $218 .^{23}$ I will not study the entire corpus of extant $L D P$ manuscripts here as that would amount to an altogether different kind of study. Consequently, when I speak of 'the $L D P^{\prime}$ ' in my discussion, this is to be understood as a functional denomination; one must be mindful that each individual manuscript has its idiosyncrasies. However, the combined text of these two manuscripts, in my estimation, is sufficiently representative for the aggregate of ideas that the $L D P$

20 The patronage of the royal French court also explains Corbechon's polemical outbursts against Bartholomaeus' "convenient amnesia concerning the Norman Conquest" in the LDP chapter about England (Byrne 1981, pp. 100-1).

21 Significantly, thirteen parchment manuscripts of Bartholomaeus' De proprietatibus rerum were produced in the same century, prompting Harris (2020) to remark that "it is certainly tempting to wonder whether some late-medieval readers of nature encyclopaedias really did retain a sense that a book about animals was best written on animals-at however catastrophic a cost to the local veal population" (p. 108).

22 For instance, Corbechon's French version lay at the basis of Vicente de Burgos' Castilian translation (printed in 1494) and "indirectly contributed to the imposition of a learned lexicon in Spanish" (Eggert 2014, p. 277).

23 The latter complements the former's lacunae (cf. infra). BnF fr. 9140 (Corbechon 1480) was commissioned by Jean du Mas, lord of l'Isle-sur-Arnon (in the province of Berry), and lavishly illuminated by Evrard d'Espinques. Less is known about BnF fr. 218 (Corbechon 1485), except that it was illuminated by the Master of Yvon du Fou. 
manuscript corpus evokes about porcinity. Central to my analysis is the $L D P^{\prime}$ s 18 th book on terrestrial animals, specifically chapter 5, le porc sengler ('the wild pig'); chapter 60, le hericon ('the hedgehog'); chapter 61, le porc espi ('the porcupine'), and most of all chapters 85 and 97, which pertain to le porc ('the pig') and la truie ('the sow'), respectively.

\section{The Properties of Things ${ }^{24}$}

The LDP departs from the Augustinian view of nature-reflecting immediate divine commands-in favour of the newly translated natural philosophy of Greek and Arabic thinkers who regarded nature as an independent operation of autonomous sequences of causes and effects. So, while God had created the natural order of things and He alone retained the power to miraculously suspend it, nature was now understood to be an agent with relatively predictable principles (Daston and Park 1998, p. 49). Much of book $18^{\prime}$ s taxonomic descriptions of animals (i.e., their defining appearance, structure, physiology, and behaviour) are therefore derived from Aristotle's History of Animals and Pliny the Elder's Naturalis Historia. Although this compilation of such at first glance zoological information could seem to suggest that the LDP heralded an early form of empiricism, this was assuredly not the case. Ambrose of Milan famously counselled that "we cannot fully know ourselves without first knowing the nature of all living creatures" (Ambrose 1961, p. 229). Ambrose's counsel also applies to the LDP as its zoological expositions are complementary to the encyclopaedia's homiletic theological scheme, within which nature contains clues to God's plan for humanity. The LDP thus builds on the transcendental hermeneutics of the influential Physiologus and bestiaries, widely popular lists of nonhuman species that describe nonhumans in terms of how they purportedly reveal deeper truths about the cosmos. ${ }^{25}$ Learning to read the Book of Nature, a "Christian interpretation of nature as a manifestation of the divine", gave humans a tool to unravel the meaning of God's cosmic hierarchy and to fathom humankind's own position therein (Goehring 2013, p. 29). These works are thus not to be regarded teleologically, as serious proto-scientific work, except in strictly mediaeval terms, when 'science' meant the pursuit of all truth, including metaphysical truth (Salisbury [1994] 2011, p. 89). ${ }^{26}$

Given its religious ideological framework, it is no coincidence that the $L D P^{\prime}$ s entries also frequently reference Church Fathers, such as Basil of Caesarea and-in particularIsidore of Seville, whose reflections situate nonhuman species in a subordinate position within the grand scheme of God's anthropocentric hierarchy. In this view, nonhumans did not exist in their own right; they were mere vessels of a divine imperative-humankind's domination of God's creation, as prescribed in Genesis 1: 26-29. The LDP's marriage of natural history to theology was made possible by the 'new' Aristotelianism that developed due, in large part, to Michael Scot's De animalibus, which translated Arabic versions of Aristotle's Historia animalium, De partibus animalium and De generatione animalium, and provoked what Harris (2020) coins "the thirteenth-century Animal Turn" (p. 16). A corollary of this renewed desire to seek knowledge for its own sake and systematise zoological and natural historical knowledge was Aristotle's legacy of anthropological difference that separated humans from other animals (Harris, p. 17). Aristotle's hierarchy of the natural world, in which humankind is the pinnacle of earthly animals, bolstered

24 All transcribed passages and English translations from the Livre des propriétés des choses in this article are my own. While modern French editions of some of the other books in the LDP have been published, an edition of the entire 18th book-though in the making (Van den Abeele et al. 1999)-is yet to appear. Modern French translations of particular excerpts do exist, notably Michel Savant's edition of the introduction to the 18th book (Bianciotto 1980, pp. 243-63) and Bernard Ribémont's edition of a selection of animal chapters (Ribémont 1999, pp. 273-86), i.e., the ram, the boar, the asp viper, the cat, the basilisk, the elephant, the flea, and the unicorn. To my knowledge, the chapters that I discuss here-i.e., the porcupine, the pig, the hedgehog, and so on-have not appeared in a modern edition yet.

25 Bestiaries are descendants of the Physiologus (c. 200), a compendium of zoological information about quotidian and fantastic animals that linked natural history to the Early Christian message by decoding the divine allegories or symbols of biblical or moral truth in nonhumans' physiology and behaviour (Cohen 2008, p. 45).

26 This is not to suggest that a scientific attitude lay beyond the capacity of mediaeval scholars. Indeed, "when driven by immediate interests for which accurate information was required" mediaeval scholars could attain an "acuity of observation ... in a way that is quite modern" (Wilkins 2009, p. 45). 
biblical precepts of human unicity and, insidiously, reinforced anthropopoietic models that were grounded in the exploitation of nonhuman life and the exclusion of so-called animal properties from human identity (Pareles 2015, p. 19). ${ }^{27}$ Accordingly, the LDP considers nonhumans primarily in terms of their functional, medicinal, nutritional, and symbolic value to humans without regard for how their instrumentalisation affected the nonhumans themselves. ${ }^{28}$ Near the end of the introduction to the 18th book, the LDP submits that "all animals are ordained to serve Man". ${ }^{29}$ From this maxim, the LDP derives the following systematic classification for terrestrial animals:

therefore some beasts are given to us on our journey to eat, such as sheep and cows and deer and many others. Some are given to us to help us, like horses, camels, and their similars. The others are given to us for our entertainment, such as monkeys, dogs, and many other beasts. Some are given to us for consciousness of our fragility, such as lice and fleas and other vermins that ensue from our poverty. The others make us fear God, such as lions, bears, and serpents, which make us fear God and cry out because of the fright that we have for such things. The others are given to us to lend remedies against multiple illnesses, as it appears [with] serpents of which one makes the theriac which heals us of many ills. ${ }^{30}$

In other words, the $L D P$ classifies terrestrial animals into:

- Livestock to satiate human appetite;

- Draught animals to assist humans with heavy labour;

- Pets to entertain humans;

- Vermin to remind humans of their fragility;

- Predators to instil humans with awe and fear for God's might;

- Medicinal creatures to remedy human ailments or illnesses.

Notably, humankind is not classified within this taxonomy. Instead, the taxa inherently pivot around human needs, suggesting that nonhumans were created solely for the telos of human exploitation and edification.

To take this anthropocentric form of categorisation for granted is to perpetuate and reify the instrumental value of nonhumans for human self-achievement. I analyse the $L D P$ through a counter-hegemonic, nonhuman-centred close reading to destabilise the source's anthropocentrism. This entails treating the nonhumans it represents not as anonymous objects of knowledge in a history of human protagonists, but as agential partners in knowledge (Marchesini 2016a, p. 165), to underscore the relational ontology of humans and nonhumans in their long history of coexistence. By conjugating with nonhuman Others and recognising the value of their alterity, the human component in anthropocentrism becomes decentred. This somewhat contrarian approach aspires to a preposterous history, which is pre-posterous in the sense that it "endorses the present as a historical moment in the act of interpretation itself", thereby allowing one to learn from the object under scrutiny,

27 Thirteenth-century theologians maintained varied and nuanced ideas about nonhuman capabilities, however. Though many thinkers did subscribe to the notion that nonhumans are incapable of reason, Oelze (2018) has demonstrated that the mediaeval debate about this topic was nuanced and complex as several thinkers did believe that nonhumans were capable of certain rational processes, such as reasoning, judging, or employing prudence. Likewise, Wei (2020) has recently argued that Parisian theologians enjoyed considerable freedom in exploring the boundary between humans and nonhumans as they saw fit, provided that they acknowledged humankind's unique capacity for reason. He observes that there was "tremendous diversity and creativity in the strategies that they adopted for making sense of similarities in relation to difference, for holding similarity and difference in productive tension" (pp. 202-3).

28 Hence my skepticism for the notion that nonhumans which supposedly retained "symbolic, transcendent characteristics ... enjoyed a special proximity to human beings by virtue of embodying specific human and metaphysical traits" (Cohen 1992, p. 102) and the claim that encyclopaedic works like bestiaries and the LDP placed "the identity of the animal itself" front and centre (Van Molle 2012, p. 468).

29 "Derechief toutes/bestes so[n]t ordo[n]nees au service d'o[m]me" (Corbechon 1480, fol. 330r).

30 "pour ce aucu[n]es bestes/no[us] so[n]t do[n]nees en n[ot]re viage po[ur] me[n]/gier si co[mm]e les mouto[n]s et les boefs et/les cerfz et m[u]lt d'aultres aucu[n]es no[us]/so[n]t do[n]nees po[ur] no[us] aider co[mm]e les ch[ev]aulx/les chameulx et leurs semble[n]s Les aul/tres no[us] so[n]t do[n]nees po[ur] n[ot]re esbatem[en]t/sico[mm]e les singes les chie[n]s et plusieurs/aultres bestes aucu[n]e no[us] so[n]t do[n]neez/po[ur] co[n]goissance de n[ot]re fragilite/sico[mm]e les poux et les puces et aultres/vermi[n]es q[u'] y sse[n]t de n[ot]re povrete les/ault[re]s no[us] fo[n]t doubter dieu sico[mme] les/lyons les ours et les serpe[n]s q[ui] no[us] fo[n]t/doubter dieu et reclamer po[ur] la pao[ur]/q[ue] no[us] avons de telles choses Les ault[re]s/no[us] so[n]t do[n]nees pour bailler remedez/co[n]t[re] pluiseurs malades co[mm]e il app[er]t/des serpe[n]s do[n]t on fait le triacle q[ui] no[us]/guerist de m[u]lt de maulx" (Corbechon 1480, fol. 330r). 
"enable it so speak and to speak back, as a full interlocuter" in debates about knowledge and meaning (Bal 1999, p. 18). To carefully examine the preposterous, as Patricia Parker winningly proposes, is to imagine "the presentation of an order authorized as 'natural' as instead rhetorically produced and to become aware of the workings of 'smooth discourse' the histories it forges and the authority it creates" (Parker 1992, p. 213). In this case, that means that I treat the $L D P^{\prime}$ s hierarchy of nature and its scripts of porcinity with suspicion. I attend to how this discourse prescribes, rather than describes, an order to nature's species, thereby naturalising the structural exploitation of nonhuman species and reinforcing a harmful model of human identity.

\section{Porcinity as Abjection}

Porcinity refers to a group of mostly undesirable traits-physiognomic, behavioural, spiritual—that humans associate with pigs. As the mediaeval concept of species was not narrowly defined, animals could reportedly become altered, perhaps even converted into other creatures. I propose that late mediaeval porcinity lay in the hazy field between humanity and nonhumanity as an ontological twilight zone of doubtful, perverted humanity. Consequently, whenever humans associated their conspecifics with supposed porcine traits, the latter's integrity as human beings could be called into question. Such discourses of porcinity furnished mediaeval Christians with an insidiously convenient rhetorical device to dehumanise and persecute other humans. For this to be a felicitous stratagem, porcinity necessarily had to be subhuman (rather than inhuman): sufficiently 'Other' to be at odds with humanity, yet still somewhat applicable to humans. Porcinity thus consisted of abject matter, defined by the psychoanalytic philosopher Kristeva (1982) as those parts of human identity that it seeks to expel, reject, dissimilate from and yet never seems to be able to truly part from (pp. 3-4). I will demonstrate that much of the disgust in descriptions of porcinity heralds the abject in how it articulates a profound anxiety for porcinity's potential pollution. Disgust devaluates that which it touches to proclaim its "meanness and inferiority ... It is thus an assertion of a claim to superiority that at the same time recognizes the vulnerability of that superiority to the defiling powers of the low" (Miller 1997, p. 9). Disgust is therefore an anthropopoietic tool that prescribes a desired model of humanity. It is defined in moral and social terms, aimed to protect this model by framing that which it seeks to expel as dangerously contagious.

Disgust and-by extension-discourses of porcinity are wound up in the tension field between the clean and the unclean, which the anthropologist Douglas ([1966] 2001) has famously investigated. The polluted nature of porcinity and its spiritual uncleanness were clearly indicated in the Mosaic laws of Deuteronomy 14 and Leviticus 12. Among quadrupeds, cloven-hoofed ruminants were considered clean and fit for consumption or sacrifice. Though cloven-hoofed, suids such as the domestic pig or the European wild boar did not ruminate. This taxonomical aberration rendered both species unclean and thus unfit for human consumption (Fabre-Vassas 1997, pp. 5-6). ${ }^{31}$ Jewish doctrine therefore proscribed the use of pork in Jewish cuisine. ${ }^{32}$ Christians, however, favoured a figurative interpretation of these laws and mocked what they perceived to be Jewish people's literalism, leading to the accusation that Jews could not interpret the Bible's prescriptions spiritually because they were too preoccupied with base carnal concerns (Strickland 2007, pp. 217-19). The spiritual uncleanness of pigs was further exemplified in the New Testament, Matthew 8: 30, in which Jesus exorcised a man's demons and drove them into a herd of pigs who then threw themselves to their deaths. Within the Christian imaginary, pigs could also be emissaries of the devil, who might even assume a porcine shape himself, grunting like a piglet and wallowing in excrement (Pastoureau

31 The prohibition of consuming pig meat likely stems from ancient experiential knowledge of the health hazards, such as a roundworm infection known as trichinosis, that ingesting undercooked pork entails (Yerkes 1923, pp. 27-28).

32 For a brief synthesis of the mediaeval legacy of Jewish dietary regulations, see: Pareles (2015, pp. 190-93). 
1987b, p. 52). ${ }^{33}$ Likewise, pigs often figured in stories as personifications of human vices such as gluttony (gula), lust (luxuria), filth (sorditas), laziness (pigritia), and wrath (ira) (Pastoureau 1987b, pp. 52-53; 2011a, p. 61), as heralds of the impending apocalypse (Schouwink 1984), or as contra-exempla, as was the case with the misogynistic pictorial topos of La Truie qui file ('The spinning sow') which lamented that human women prized sloth, prostitution, and bawdiness over their so-called womanly duty of spinning clothing for their husbands (Jones 1991, p. 207).

The connotations of porcinity with all things foul and diabolical thus ran deep. Mediaeval viewers also "made a direct connection between deformity and sin", consciously using the body "as a sign of legible guilt, which was the end result of sin" (Mittman 2003, p. 8). In other words, physiognomy that diverged from Christian norms ('deformity') was understood to be monstrous in the sense that it demonstrated (from the Latin monstrare) a creature's true, sinful nature (Williams 1996). Conversely, the inherent moral corruption of porcinity manifested externally, to be recognised and contemned by anyone who understood the significance of porcine corporeal deformities. Hence, I will now turn to the $L D P^{\prime}$ s descriptions of porcine physiognomy and how these informed broader spiritual reflections on porcinity and sin.

\section{A Foul Mouth}

One of the most distinguishing aspects of porcine physiognomy was a flat, cylindrical snout with downwards inclination. According to the $L D P$, this downwards inclination was a particularly damning trait for any animal:

The mute beast has its face inclined towards [the] earth, which is the material whence it originated, but Man who is a reasonable beast goes straight forward and has his face raised towards heaven, to his creator, and this is great nobility according to a poet, and because of this Basil says that if Man is governed by the desire of his body while obeying to the lustfulness of his stomach, he has become equal to senseless beasts of burden and he is rendered similar to them. ${ }^{34}$

The $L D P^{\prime}$ s paraphrase of Basil of Caesarea underlines that the inclination of one's face indicates what a creature is preoccupied with most. ${ }^{35}$ Creatures whose visage faced the earth, the base material from which all creatures were made, were ostensibly too concerned with earthly delights to be reasonable and virtuous. Humans, made in God's image with their faces raised upwards towards their heavenly maker, thus had to maintain this posture both literally and figuratively in order to qualify for citizenship in the kingdom of heaven. I find the conviction that a species is not fixed particularly evocative in this excerpt. When a human behaves outside the prescribed parameters of their kind, they are not simply like a senseless beast, they have actually perverted their human essence and thereby devolved into a lower animal. This idea may seem preposterous to those who subscribe to the tenets

33 Some manuscripts of the $L D P$ also depicted the devil with porcine features. One such image of the fallen angel Lucifer as a hairy monstrous hybrid with humanoid, suine and other nonhuman features can be found in Corbechon (1480), fol. 18v.

34 "La bes/te mue a la face enclinee vers terre/q[ui] e[st] son materiel co[m]menceme[n]t mais/ho[m]me q[ui] e[st] beste raiso[n]nable va tout/droit et a la face levee vers le ciel a so[n]/create[ur] et ce luy est tresg[ra]nt noblesse/sico[mm]e dit un poete et pour ce dit Vasille/se ho[m]me se gouv[er]ne al la voulente/en obeissant a la luxure de son ve[n]/tre Il est aco[m]p[ar]agie aux folz jume[n]z/et est fait se[m]blable a eux" (Corbechon 1480, fol. $327 \mathrm{v}) ;$ "La beste/mue a la face enclinee vers terre/qui est son materiel co[m]mencement/mais ho[m]me est beste raisonnable et/va tout droit et a la face levee vers/le ciel a son createur et ce luy est tresgra[n]t/noblesse sico[mm]e dit un poete/et pour ce dit Vasille q[ue] se ho[m]me se/gouverne al la voulente de son corps/en obeissant a la luxure de son ventre/il est acomparage aux folz jouve[n]ceaulx/et est fait semble[ns] a eulx" (Corbechon 1485, fol. 236r). The latter manuscript writes that humans who submit to the desires of their bodies are rendered equal to "senseless adolescents" rather than senseless beasts of burden. Interestingly, this not only diverges from Basil's original phrasing (cf. infra) but it also suggests-rather anthropopoietically I might add—that adolescents are less human than adults. Though not an uncommon perception, it can be quite harmful to think of minors as creatures that have not yet 'accomplished' humanity.

35 Basil of Caesarea wrote: "The herds are earthy and bent toward the earth, but man is a heavenly creature who excels them as much by the excellence of his soul as by the character of his bodily structure. What is the figure of the quadrupeds? Their head bends towards the earth and looks toward their belly and pursues its pleasure in every way. Your head stands erect toward the heavens; your eyes look upward, so that, if you ever dishonor yourself by the passions of the flesh, serving your belly and your lowest parts, 'you are compared to senseless beasts, and are become like to them'. A different solicitude is becoming to you, namely, to 'seek the things that are above, where Christ is,' and with your mind to be above earthly things. As you have been molded, so dispose your own life. Keep your citizenship in heaven" (Saint Basil of Caesarea 2003, p. 138). 
of modern evolutionary biology. However, it bears repeating that mediaeval Christians thought in 'kinds' of creatures rather than fixed species. Moreover, they subscribed to the common notion that humankind occupied a precarious position midway between spiritual and bestial creatures as the immortal human soul was housed in a mortal animal body. ${ }^{36}$ Humans could only maintain their exalted rank in the order of creation if they exercised their supposedly unique capacity for reason and logic to keep the unruly urges of their bestial form at bay. ${ }^{37}$

The above-quoted injunction could therefore incite profound terror because it implied that one could lose one's humanity and become subhuman or even nonhuman if one did not behave reasonably or model their posture according to the paradigmatic idea of human uprightness. $^{38}$ This way, Christian modelisations of humanity could exclude certain forms of undesirable behaviour, "but in strange fashion: not radically enough to allow for a secure differentiation between subject and object, and yet clearly enough for a defensive position to be established-one that implies a refusal but also a sublimating elaboration" (Kristeva 1982, p. 7). This abjection is rendered more explicit by the LDP's descriptions of monstrous human-nonhuman hybrids such as onocentaurs (humans that had devolved into a human-donkey or human-horse hybrid) and wild men (excessively hairy humanoids that were likened to satyrs and incubi because of their lechery). ${ }^{39}$ These humanoid creatures-which the LDP never clearly situates within its own animal taxonomysomatically exemplified what became of humans that fell prey to their own unbridled carnal desires. The $L D P^{\prime}$ s invocation of Basil here is thus an emphatic reminder that the encyclopaedia's chief concern is not so much in nonhuman species themselves as it is in subjecting nonhuman physiognomy to a despotic 'faciality' (Deleuze and Guattari [1980] 1994) — which "takes the human animal and makes it Man ... it takes the animal and makes it bestial" (Wolfe 2003, p. xx) — that prescribes how humanity can only be achieved by avoiding allegedly nonhuman behaviour and posture. In other words, "becoming human consists in endlessly seeking to overcome our animality" (Chasseguet-Smirgel 2011, p. 150; Kay 2017, p. 68).

Unlike reasonable animals (i.e., humans), species with a porcine snout were physically incapable of altering the inclination of their snout. ${ }^{40}$ Yet, what was perhaps even more damning - bearing in mind the anthropopoietic politics of faciality-was the fact that pigs primarily used their snout for purposes that only seemed to confirm the base nature that their physiognomy implied. Pigs have long been known for avidly burrowing their snout in the earth. Etymologically, the French term porc goes back to the Latin porcus, which in turn can be retraced all the way to the Proto-Indo-European root pork-o- ('digger') (De Vaan 2008 , p. 481). This porcine inclination is also described in the LDP:

The boar loves roots and cuts the earth with his teeth to have its grease. ${ }^{41}$

36 This dual and dynamic notion of humanity, as famously expressed in Plotinus' Enneads (Plotinus 1967, p. 69), Augustine's City of God (Augustine 2008, IX:13, p. 98 and XII:21, p. 288), and Judaeo-Arabic literature (Malter 1912) has an extensive and abiding career (cf. Wildberger 2008; Lloyd 2012; Toivanen 2016).

37 Brumberg-Chaumont $(2017,2018,2021)$ recent work draws attention to the formative role of educational institutions, even for young children, in rendering this ambivalent notion of the homo logicus commonplace in thirteenth-century discourse and ensuring its lasting influence in the Late Middle Ages.

38 Steel (2011, particularly pp. 44-58) devotes great attention to the homo erectus topos and cites several examples of this corporeal tradition (also see $\mathrm{p}$. $47, \mathrm{n}$. 33). In addition to bipedalism, several mediaeval authors presented the possession of hands as another crucial element of the human body and its exceptionalism. As Steel observes, "to be without hands would force humans to graze with eyes downcast, cut off entirely from documentary culture and from being recognized as humans" (p. 50). In the LDP's chapters on porcine animals, this concern for (the differentiating force of) human hands is not indicated.

39 See: Corbechon (1480), fol. 354r (about the onocentaur) and fol. 355r (about the pelu or satyr). Esther Cohen (1994) observes that people who suffered from mental illness-understood to be a deprivation of reason-legitimised belief in the unnerving existence of feral "semi-humans who lived in wild places" (p. 65).

40 An unlikely example from some fifteenth-century bestiaries, worth briefly mentioning here is the marine equivalent of the pig, the so-called porc de mer ('sea pig'), which was depicted with a pig face, scales instead of bristles, and fins for legs (Pastoureau 2011b, pp. 177, 185). The LDP does not appear to discuss such a creature, not even in its 13th book (on water and the animals that live therein), which is why a more detailed discussion of these hog fish is beyond the scope of this article.

41 “Le sen/glier aime la raci[n]e et coppe la te[r]re a sez/dens po[ur] en avoir la gresse" (Corbechon 1480, fol. 331v). 
The sow burrows in the earth with her snout, and does not return from below, to get the roots that are there. ${ }^{42}$

Though their omnivorism allowed pigs to be reared on poorer land than other animals (Jørgensen 2013, p. 389) - rendering them convenient livestock—it was also a trait that was regarded with suspicion. While rooting for meat, tubers, or even garbage and excrement, suids willingly burrowed their nose and mouth (snout), vital sensory organs, in the muck, a mundane and polluting substance. ${ }^{43}$ In villages and cities where pigs freely roamed the streets, "people would have been constantly reminded of their propensity to eat disgusting things" (Rogers 2012, p. 20). Dung was particularly disgusting. Firstly, from an ethological perspective, the instinctive aversion to the pungent smell of excrement is a vestigial neurological defence mechanism: material which looks or smells foul often contains contagious or potentially lethal pollutants, so the human brain's disgust reflex functions "as a warning signal against [excrement] and the danger that it may contaminate one's environment and imperil health" (Bayless 2012, p. 30). Secondly, dung was especially vile in Christian culture because it endangered both body and soul. The Christian aversion to excrement, the foulest kind of dirt, thus masks a fear of mortality because it "exposes the corruptible, mortal animality of the body even as it violates essential categories, transgressing the boundaries between inside and outside, whole and fragmented, pure and foul" (Bayless 2012, p. 30).

At times, pigs made their way into graveyards, where they violated sacred resting spaces, exhuming and feasting on the cadavers of deceased humans (Pastoureau 2000, p. 192), thus exacerbating the fear of contagion with mortality. In the Bible, Numbers 19: 11 and Leviticus 22: 4 both prohibit touching corpses because they are unclean. Moreover, pigs feasting on human cadavers raised concerns about anthropophagy and human cannibalism (if humans consumed pigs who had eaten from human cadavers) as it was humans who were supposed to eat pigs, not the other way around (Steel 2011, p. 124). Furthermore, the human body housed the soul so safeguarding the integrity of this fleshly vessel was paramount to protecting one's purity. The ingesting organs (mouth and nose) are particularly vulnerable because they are places where "the body's seal is already broken", where foreign substances may enter and defile the sanctity of the body (Miller 1997, pp. 58-59, 97-99). In the Livre du roy Modus et de la reyne Racio (1354-1377), a moralised treatise on how to hunt nonhumans, the character of Queen Reason demonstrates how porcinity could be fused with these spiritual concerns as she likens how pigs root in the muck to sinners who, "thinking lightly of heaven, rootle in the sensual gratifications of wine, food, and the body" (Thiébaux 1969, p. 283).

Another aspect of porcine snouts was that they could produce short, low guttural sounds, a vocalisation known as grogner ('grunting'). ${ }^{44}$ In the $L D P$, grunting is another marker of porcinity. Piglets were known for the swift development of their capability to differentiate one's cries from another as they reportedly practised their voices often. ${ }^{45}$ Additionally, female boars grunted to warn other predators not to approach their den. ${ }^{46}$ It should come as no surprise then that Queen Reason also allegorises the danger of the boar's mouth into an instrument of false counsel that exhorts others to heed the commandments of the Antichrist (Thiébaux 1969, p. 283). The porcinity of grunting is further evidenced in how the LDP connects suine animals to porcupines. Curiously, the term 'porcupine' refers to a pig (porc-espine, literally: 'quill pig'), even though these animals-aside from being mammals—share no significant zoological similarities with suids. Significantly,

42 "La truie fouist la/terre au groi[n]g et la retour/ne ce dessus desoubz po[ur] avoir les ra/ci[n]es q[u'i]l y so[n]t" (Corbechon 1480, fol. 358r).

43 Relating the human face to the porcine snout is nearly inevitable because of anthropomorphic pareidolia, the human tendency to detect human likeness in the nonhuman (Epley et al. 2007, 2010; Liu et al. 2014).

44 This calls to mind the Testamentum porcelli ('Piglet's Will'), a late-antique parody that "developed quasi-autonomously as a literary genre" during the Middle Ages and afterwards (Fabre-Vassas 1997, p. 285). The star of this notorious animal testament is Grunnius-from the Latin grunnire ('to grunt'), see: Steel (2011, pp. 203-6).

45 "les pors s'ent[r]ainie[n]t et co[n]/gnoissent la voix l'un de l'autre" (Corbechon 1480, fol. 355v).

46 "la femelle ne blesse poi[n]t ceulx qui so[n]t en esta[n]t car elle ne blesse q[ue] du groi[n]g" (Corbechon 1480, fol. 331v). 
in a departure from the original Latin text, Corbechon in fact invented the following explanation:

The porcupine according to Avicenna is called Herinancius... and is similar to a hedgehog but he is much larger.... This beast has the grunt of a pig and a back covered in spines. ${ }^{47}$

This excerpt, particularly Corbechon's fabricated etymology, suggests that a porcupine's grunt-arguably a rather minor point of resemblance at best-was deemed to be so typically porcine that their entire species had to be named after pigs-despite their more apparent similarity to hedgehogs. In MS BnF fr. 218, an illuminator even contrived to establish visual likeness between suids and porcupines on the first page of book 18 by depicting a hairy black swine with a curly tail near the top left and a bristling porcupine near the bottom right corner. ${ }^{48}$ Significantly, the porcupine is drawn in such a way that it physically resembles pigs. Not only does it have a fairly porcine snout (elongated, cylindrically shaped), but it also has a curly tail that resembles the pig's tail almost exactly. These two features are, however, mentioned nowhere in the $L D P^{\prime}$ s chapter on porcupines nor do images of porcupines in other fifteenth-century manuscripts appear to depict them as such either. ${ }^{49}$ I intuit that this visualisation could be an "iconographic departure" (écart iconographique), a subconscious 'slip of the image' (lapsus figurae) of the illuminator (Dittmar 2013, pp. 326, 334). The LDP's visual representation of a porcupine then reflects neither the $L D P^{\prime}$ 's description of the animal nor its actual morphology as much as it does the artist's tacit assumption that a porc-upine must have been considerably similar in kind to a pig.

The $L D P$ 's entry on the porcupine also demonstrates Corbechon's omission of terms which could confuse readers as he left out the term cirogrillus, which is mentioned as a synonym for porcupines in both the original Latin version and in the English translation (cf. Anglicus 1492, 18.61; Trevisa [1975] 2019, p. 1212). Corbechon does briefly reference the cirogrillus in its proper entry (chapter 56 , about the grille), describing it as

a little and feeble beast, loaded with prickles and smaller than the hedgehog as the gloss on the Book of Leviticus says. The grille and the cricket are one and the same and [he] is thusly named for the sound that he makes with his voice, as Isidore says in his twelfth book. ${ }^{50}$

Considering that the cirogrillus-actually the Syrian hyrax-has a long history of being confused with a variety of other species (cf. Dines 2008), it is fairly unsurprising that Corbechon omitted the term from his porcupine chapter, preferring instead to give the animal a separate entry. Corbechon also intervenes in that entry, adding that the grille and the cricket are essentially the same animal, something not stated in the Latin and English versions (cf. Anglicus 1492, 18.56; Trevisa [1975] 2019, pp. 1207-8). His connection of the grille with the cricket demonstrates that he did not mention the cirogrillus in the porcupine entry because he associated grille with the Latin term for 'cricket' (Pinkster 2014, p. 447, s.v. "grillus"). The confusion of the cirogrillus with porcupines in the Latin and English versions, however, suggests that Bartholomaeus and Trevisa had 'grunter' or 'piglet', the Ancient Greek meaning of the term gryllus, in mind (Montanari 2015, p. 444, s.v. " $\gamma \rho \tilde{v} \lambda \mathrm{o}^{\prime}$ ")—underlining the porcinity of the porcupine's grunt. In his translation of the porcupine entry, Corbechon thus remained true to the spirit of this Ancient Greek 'grunter' association, without explicitly invoking the confusing cirogrillus.

\footnotetext{
47 “Le porc espi selon Avic[en]ne/e[st] appelle herina[n]cius ... / /et e[st] se[m]ble[ns] a un heriçon mais il e[st] plus/g[ra]nt. ... Ceste bes/te a le groing d'un porc et le doz char/gie despines" (Corbechon 1480, fol. 349v).

48 The image can be found in Corbechon (1485), fol. 325r.

49 For instance, see: Afghans hunting porcupines in Marco Polo's Livre des merveilles (Polo 1412, fol. 18r), a porcupine in the Book of Hours of Marguerite d'Orléans (N.N. 1438, fol. 176r), and a porcupine depiction by the Master of the Mazarine Hours in another LDP manuscript (Corbechon 1415, fol. 296v).

50 “Grille e[st] une petite beste [et] foi/ble chargee despines [et] e[st] me[n]die q[ue] le/hericon co[mm]e dit la glose sur le livre/des levites Le grille [et] le gresillo[n] cest/tout un [et] est ainsi no[m]me po[ur] le son/q[u'i]l fait de la voix co[mm]e dit Ysid[ore] ou xii[e] livre" (Corbechon 1480, fol. 348v).
} 


\section{Mired in Sin}

Another porcine characteristic was hairiness. Mediaeval domestic pigs were not only smaller but also much hairier than their descendants (Comet 1997, p. 20). The smooth, pink pig that people generally envisage when they think of a domestic pig nowadays is in fact a Chinese breed of pig that was introduced in Western pig husbandry only in the eighteenth century. Previously, at least up to the sixteenth century, European domestic pigs and boars were nearly indistinguishable from each other (Steel 2011, p. 182). Their bristliness was something they also shared with several other species, notably the hedgehog and the porcupine. According to many bestiaries, the hedgehog's red bristles were external indices of its vile nature, resembling the unkempt red hair of Judas Iscariot in European art and antisemitic discourse (Pastoureau 2011b, p. 95; Ryan 2019, p. 233). Moreover, in mediaeval narratives, hair functions as "a sign of animality and the opposite of all civilized life" because, far more so than nakedness, ignorance, or heresy, it was excessive hairiness that made a creature beastly and subhuman (Pastoureau 2011a, p. 212). ${ }^{52}$ The baseness of pigs, hedgehogs and porcupines was also evident because of their short legs, which ensured that their entire body was close to the polluting ground. Hence, porcine animals skin could easily be soiled by all kinds of foul material that might cling to their coarse fur. The $L D P$ 's condemnation for this is particularly notable in chapters 85 and 95 , which pertain to the domestic pig and to the sow, respectively, where the LDP insists that suids, especially sows, are exceedingly disgusting creatures. ${ }^{53}$

The pig is a foul beast as Isidore says in [the] twelfth book that speaks of manure and of filth and [the pig] lies in the muck and it rests in a foul place. ${ }^{54}$

The sow is a foul and gluttonous beast which runs in the muck as Aristotle says. ${ }^{55}$

The $L D P^{\prime}$ s association of sows with gluttony attests that pigs' dirtiness signifies more than a skin-deep antipathy to their habitat, it also indicates moral aversion. Disgust and moral indignation are often synonymous (Miller 1997, p. xi). To preserve the duality of the term's meaning, I have translated all invocations of the term orde in the LDP as 'foul' (rather than 'filthy'). Additionally, I translate boue as 'muck' rather than 'mud' to preserve and accentuate the abject, disgusted connotations of the Middle French term. I do so because human conceptualisations of dirt involve "reflection on the relation of order to disorder, being to non-being, form to formlessness, life to death" (Douglas [1966] 2001, p. 5). Muck or uncleanness is essentially "matter out of place"; it indicates at once the presence and disordering of a system (Douglas [1966] 2001, pp. 36, 41). In other words, dirt signifies that which lies outside a given anthropopoietic model; it materialises those key values that are antithetical to the aforesaid model.

As pig rearing became increasingly urbanised by the Late Middle Ages, the image of domestic pigs roaming the streets of human settlements was no longer uncommon, resulting in new legal ordinances and statutes intended to gain more control of these wandering nonhumans (Geltner 2019, p. 45). The most common complaint that human citizens made was about pigs' foul odour (Briand 2016, p. 40). This is hardly surprising, given that pigs wandered through streets that, at the time, were often littered with waste

52 Also see my remarks on the pilosus, the hairy wildman, supra, and Thompson (2018) work on how mediaeval authors anthropopoietically linked hair or hairiness to bestial traits to dehumanise certain (kinds of) people.

53 Steel (2011) observes how the entries on pigs, boars, and sows of the English translation cross-reference each other, thus muddling the categories of wild and domestic pigs (p. 181). This is also the case in the original Latin De proprietatibus rerum (Anglicus 1492, 18.6; 18.85; 18.97). Interestingly, Corbechon's translation departs from this as his entries on pigs do not cross-reference one another. This is a typical intervention from Corbechon, who sought to make Anglicus' work more concise in several ways, among which omitting the cross-referentiality of Anglicus' entries (cf. Ribémont 1999, pp. 39-40). As a result, the Middle French entries on pigs evoke the impression that pigs, boars, and sows-though similar in some respects-were ultimately rather self-contained species. Still, the $L D P$ is not clear about whether or not chapter 85, du porc, pertains to the domestic pig specifically. However, given that boars have at this point already received an extensive entry of their own in chapter 5, as do sows in chapter 95 , it seems reasonable to assume that chapter 85 was mainly devoted to the domestic pig, which otherwise would have no entry of its own.

54 "Porc e[st] une orde beste sico[mm]e/dit Ysid[ore] ou xiie livre q[ui] se p[ar]le/de fiens et de ordure et se gist/en la boue et en lieu ort se repose" (Corbechon 1480, fol. 355v)

55 "La truie est une orde beste et/gloute q[ui] se engresse en la boue si co[mm]e/dit A[ristote]" (Corbechon 1480, fol. 358r). I will address the association of pigs with gluttony later in the chapter. 
or even "clogged by citizens deliberately hoarding dung", largely because certain urban industries required dung, which made it a lucrative-albeit pungent-natural resource (Bayless 2012, p. 40). Though useful, this accumulation of excrement formed a considerable physical nuisance. Moreover, as plagues ravaged the lands, concerns intensified that dung could be a source of pollution and corruption of the air (Bayless 2012, p. 41). The association of excrement with disease and moral corruption thus rendered pigs, who relished in this muck, dangerous in both a practical and spiritual sense.

Based upon everyday familiarity with pigs and their foulness, the Livre du roy Modus et de la reyne Racio, categorised nonhuman species by their scent: fragrant or malodorous (Cohen 1992, p. 104). Significantly, pigs—and particularly boars—spearheaded the list of malodourous animals because their physique, behaviour, and character allegedly revealed their sinful glorification of the Antichrist. Apparently, the black and bristling boar resembles "many people whose spiritual light is gone" and, because he wallows willingly in the mud, he is "like those on earth who gladly serve the Antichrist and bathe in the world's ordure" (Thiébaux 1969, p. 283). Anti-Judaist discourse exploited muck's connotation with sin to dehumanise Jews, underlining their apparently porcine affinity for excrement and the spiritual corruption that it symbolised. Antisemites for instance emphasised the purported bad smell of 'the Jew' (Fabre-Vassas 1997, p. 103), claimed that Jews would rather die in a cesspool than be rescued on a Sabbath, and that they had humiliated Christ by throwing dung at him and dragging him through the muck (Bayless 2012, pp. 155-59).

Queen Reason also invokes the sow, who is singled out by the $L D P$ as a particularly foul animal, as an allegory for the sinner, who luxuriates in earthly matters and suckles his own litter-the seven mortal sins (Enders 2002, pp. 231-32, 236). Other Christian allegories also used the sow's tendency to return to her quagmire as a symbol for the relapsing sinner (Pastoureau 1987b, p. 53). Her ill repute arguably rendered the sow the mother of all porcinity, which is why depictions of the Judensau, a sow suckling bearded Jews with big ears or piglets with pointed hats (pileum cornutum), became a particularly popular caricature and iconographic theme in antisemitic propaganda as of the thirteenth century (Strickland 2007, pp. 226-27). ${ }^{56}$ Such deliberate visual conflations of Jewish people and domestic pigs demonstrate more than just a metaphor: representing sows with human heads nursing porcine Jews actually utilises hybridity to push the transformation myth to its conclusion (Fabre-Vassas 1997, p. 99). In other words, this iconographic theme could be invoked by antisemites as proof that Jewish humans inevitably devolved into something as subhuman and beastly as a pig because of their supposedly sinful values and deeds. Although the image of the Judensau itself was rare in late mediaeval France, the notion that Jews were porcine animals and "that they belonged to the sow and the sow belonged to them, was firmly grounded also in French popular culture" (Cohen 1992, p. 91) ${ }^{57}$ All over Europe, several aetiological legends circulated for Jewish doctrine's prohibition of pork. In these narratives, Jesus equated Jews with pigs or even transformed Jewish children into piglets, hence Jews could not consume pork without the risk of cannibalism (Cohen 1992, pp. 90-91; Fabre-Vassas 1997, pp. 92-94). Within the mediaeval Christian imagination, pigs and Jews were so much alike that they might as well have been subhuman kin.

For hedgehogs and porcupines, the fact that matter easily clung to their prickly bristles provided a convenient way to gather food. According to the LDP,

The hedgehog uses provisions because he mounts the vine and the trees and shakes them and makes the grapes and apples fall and then he turns himself

56 Mediaeval Jews were forced to wear the 'Jew badge' and the pointed hat to differentiate Jews from Christians and above all to "prevent sexual relations between Christians and Jews, indicating that bestiality (at worst) and miscegenation (at best) were central issues in the history of ChristianJewish relations" (Hassig 1999, p. 75). The badge was instituted in 1215 by the Fourth Lateran Council, which recommended a distinctive colour. This initially resulted in the notorious yellow badge, but both the shape and colour as well as enforcement of wearing the badge varied from region to region and evolved throughout the centuries (Fabre-Vassas 1997, p. 155).

57 I have- unfortunately — far from exhausted the myriad connections that antisemites made between Jewish people and porcine animals. For other nonhuman associations that were used to dehumanise Jews, see Sara Lipton's Images of Intolerance: The Representation of Jews and Judaism in the Bible Moralisée (Lipton 1999). 
over and inserts his stingers so that he is loaded and carries them to his fawns, according to Aristotle. ${ }^{58}$

About this beast [the porcupine], Pliny says that he throws himself on the apples like a hedgehog and thus fills his spines and further he carries one in his mouth and takes them to a hollow tree where he returns home. ${ }^{59}$

As they gathered several pieces of fruit simultaneously this way, porcupines and hedgehogs could be used in sermons as allegories for sinners: the covetous human, fearing poverty, gathers a heap of muck instead of trusting in God, just as the porcupine gathers a heap of apples with its prickles (Anthony of Padua Saint 1856, pp. 246-47; Hole 2016, p. 63). The $L D P$, however, does not establish this direct link between bristles and sin. Rather, its interest appears to be of a more pragmatic nature, underlining how the porcupine's quills can be exploited for human practical needs: "Although the meat of this beast is not good, its pelt is necessary and its spines profitable to clean drapes and robes". ${ }^{60}$ Likewise, pig bristles (soyes), could be harvested for an even wider variety of human applications. They were "uprooted and torn out of the back of this beast to be used communally" by people from several professions, such as cobblers who used pig leather to sew shoe soles, or painters who fashioned paintbrushes from pigs' hide. ${ }^{61}$ The LDP does not specify if the animals were still alive when their bristles were torn out, but it stands to reason that it was most convenient to strip their hide after slaughter.

\section{Bristling with Aggression}

In spite of his connotation to sin, the boar arguably inspired a tacit kind of approvalperhaps even reverence. Following the $L D P^{\prime}$ s taxonomy, boars were predators, creatures that God had fashioned to instil humans with fear and awe for His divine power. This sense of awe is apparent in the attribution of the term ver or verrat (from the Latin verrēs, 'boar') to the male boar because, as the LDP explains, "he is strong and virtuous". ${ }^{62}$ The male boar also embodies this prowess:

The boar has in his snout two thick, strong and quite sharp teeth with which he wounds and tears apart anything that resists him, and on his right side he has a very strong bone that he always places in front of him like a shield to defend himself. 63

In other words, the male boar's two tusks and bone, his innate physical weaponry and armour as it were, constituted a morphological source of the boar's martial virtue. Defeating a boar was therefore nothing short of an epic encounter, requiring bravery and skill (Thiébaux 1969, p. 282). Yet, his tusks, a feature which he shared with male domestic pigs at the time (Meyer 2006, pp. 18-21), were also allegorised as instruments of $\sin ^{64}$ Queen Reason argues that the boar's two sharp tusks resemble "the daggers that sinners

58 "Le hericon use de po[ur]veau[x] car il mo[n]/ te sur la vigne [et] sur les arbres [et] lez/hoche [et] fait cheoir les roisins [et] les/po[m]mes [et] puis se tourne p[ar]dessus [et]/fiche ses aguillo[n]s tant q[u'i]l en e[st] tout/chargie [et] les porte a ses faons co[mm]e/dit Aristo[te]" (Corbechon 1480, fol. $349 \mathrm{v})$.

59 “De ceste beste dit Pli[ni] qu'elle se get/te sur les po[m]mes co[mm]e un hericon et en/emple ses espi[n]es et oultre il en empor/te une en la bouche et les porte en un/arbre creux ou il repaire" (Corbechon 1480, fol. 349v).

60 "co[m]b[ie]n q[ue] la char de ceste/beste ne soit pas bo[n]ne si en e[st] la pel/nécessaire et les espines proffita/bles po[ur] nettoier les draps et les ro/bes" (Corbechon 1480, fol. 349v-350r).

61 "Les cheveulx sur le dos du porc sont/appeles soyes p[ar] lesq[u'e]lles les savet[ier]s/cousent les soulers" (Corbechon 1480, fol. 355v); "desq[ue]lles/soyes qua[n]t elles sont arrachees/et tyrees hors du dos de celle beste /usent co[m]muneme[n]t toutes gens ouvrag[e]/en cuir $\mathrm{co}[\mathrm{mm}] \mathrm{e}$ sont cordo[n]niers et autres/et pareilleme[n]t celle soye sert aux pai[n]/ctres pour faire des pinceaux les/quelx leur sont necessaires pour/asseoir leurs couleurs" (Corbechon 1485, fol. 364r).

62 "Le se[n]glier est aussi/appelle ver po[ur] ce q[u'i]l e[st] fort et vertueux" (Corbechon 1480, fol. 331v).

63 "Le senglier a en/la bouche deux gras dens biens agues/et fort do[n]t il fiert et despiece tout ce/q[ui] luy resiste et si a au coste dextre un/os $\mathrm{t}[\mathrm{re}] \mathrm{s}$ dur q[u'i]l met tousiours au deva[n]t/co[mm]e un escu po[ur] se deffendre" (Corbechon 1480, fol. 331v).

64 This arguably relates to the negative transition that Kearney (1991) observes in late mediaeval Christian connotations of the boar. Pastoureau (2011b) likewise claims that, "The courage of the animal, lauded by Roman poets, has become a blind and destructive violence under the quills of Christian authors" (p. 69: "Le courage de l'animal, chanté par les poètes romains, est devenu sous la plume des auteurs Chrétiens une violence aveugle et destructrice") 
carry to taverns" (Thiébaux 1969, p. 283). This could explain why, for all his impressive fortitude, the boar (aper in Latin) remained "a cruel and harsh beast". ${ }^{5}$ The LDP here draws on aper's etymological link to the Latin adjective asper ('harsh', 'rough'), which can mean 'savage', 'agitated', or 'threatening' when used in reference to nonhumans (Pinkster 2014, p. 86, s.v. "asper"). The hedgehog, too, was known to be "a harsh beast". ${ }^{66}$ Still, boars were defined by cruel savagery and belligerence more than any other species:

[Moses] calls beasts those that are cruel and savage and which rely either on their horns, or their teeth, or on their feet, as is the case for boars. ${ }^{67}$

According to Pliny and Avicenna, the boar is cruel, and hardly can he be tamed however much he may be castrated, which is against the custom of all other beasts. The boar is so cruel that he opposes the huntsman's arms without fear and when he is wounded, he fights boldly until death. ${ }^{6}$

Considering the high volatility that is here attributed to boars, it is no surprise that Queen Reason highlights the boar's wrath and wickedness as one of the animal's most sinful qualities, for it resembles "sinners who are lacking in charity and humility" (Thiébaux 1969 , p. 283). When opposed by such a formidable opponent as a human hunter, boars fought unrelentingly, even when injured. Regardless of whether or not their manhoodwhich the LDP implies is the usual source of these rather masculine traits-had been removed, boars remained remarkably aggressive. To Queen Reason, these are two more signs of sinfulness: the cardinal sin of pride (the boar is "too proud to flee from his pursuers; so sinners disdain to evade the devil and go instead to meet him gladly") and the boar's untameable pugnacious ways, as he "turns on his pursuers like men who turn on one another in anger" (Thiébaux 1969, p. 283).

Being difficult to domesticate was not a trait reserved solely to boars. Domestic pigs, too, retained a volatile propensity for violence. The practice of pig rearing was riddled with irreconcilable ambiguities as the domestic pig was an opportunistic omnivore, "animal-like and human-like, reviled for its appetite but useless without it, permitted to live only to be killed, but at the same time also fundamentally ungovernable, even murderous, qualities that in their aggregate bind pigs to their masters in a conflict that can never be settled" (Steel 2011, p. 186). This unpredictable capacity for violence constituted another reason for why cities increasingly drafted ordinances to regulate wandering domestic pigs. For instance, in 1404, the town of Rouvre (northeast of Paris) repaired the local gallows so three pigs who "murdered and ate" a child could be brought to justice (MacGregor 2019, p. 6). In Saint-Germain-des-Prés, less than four years later, several pigs managed to invade people's homes at least twice that year, causing all sorts of mischief that sparked the ire of local human population (Descamps 2014, p. 199). Such issues increasingly informed local authorities' efforts to restrict the amount of urban space that pigs were allowed to share with humans. From the late fourteenth century onwards, several cities in the Champagne region no longer permitted pigs to wander in every street, instructed swineherds to let their herd graze outside of town and lock them up securely in the evening, and if more than the allowed amount of pigs continued to roam the village then their owner could suffer financial sanctions or see their pigs be confiscated by the town guard (Briand 2016, p. 40).

Porcine animals were as relentlessly fierce in love as in war. Male boars skirmished violently with others for a female's interest. ${ }^{69}$ After mating, the male boar remained fiercely

65 “Le porc senglier e[st] en lati[n]/appelle aper et ideo est [i]c[i]. Le se[n]-/glier e[st] une cruelle beste et aspre et po[ur]/son asprete il e[st] appele aper" (Corbechon 1480, fol. 331v).

66 "Hericon e[st] une beste aspre" (Corbechon 1480, fol. 349v).

67 "[Moyse] appelle bestes/celles q[ui] so[n]t cruelles et sauvages et fie/rent ou de la corne ou de la dent ou/du pie sico[mm]e sont sengliers loups ti /gres et leurs sa[m]ble[n]s" (Corbechon 1480, fol. 327r).

68 "Selon Plini et Avice[n]ne le senglier/e[st] crueux et a pai[n]e le peut on ap[pri]voi/sier co[m]b[ie]n q[u'i]l soit chastre q[ui] e[st] co]n]t[re] la/coustu[m]e de toutes aultres bestes Le/senglier e[st] si cruel q[u']il se oppose sans/paour au fer du vene[ur] et q[ua]nt il en est/ia feru si se co[m]bat il hardiem[en]t co[n]tre/luy iusq[ue]s a la mort" (Corbechon 1480, fol. 331v).

69 “Le/se[n]glier e[st] m[u]lt fiere q[ua]nt il e[st] en amourz/et se co[m]bat fierem[en]t po[ur] les femelles" (Corbechon 1480, fol. 331v). 
loyal as he defended his mate and their young with tooth and claw from other predators. ${ }^{70}$ Furthermore, the prospect of death did not frighten the male undomesticated pig as he was willing to "put himself into mortal peril" for his piglets. ${ }^{71}$ His untameableness, regardless of castration, suggests that the boar's cruelty and ferocity was supposed to come from a more innate wellspring, perhaps his porcine nature. Boars shared this ferocity and protective combativeness with their evolutionary cousin, the domestic pig. The LDP returns to this notion several times, stating for instance that

some beasts are fiercely courageous, and they battle voluntarily, and especially when they are in love, like the pig. ${ }^{72}$

pigs are driven by a very great love and they know one's voice from the other, and if one cries out, all the others run toward him and they strive to deliver him to their best ability. ${ }^{73}$

Pigs, both domestic and undomesticated, were thus believed to share a deep sense of kinship with one another, a kind of love and loyalty for which they were willing to fight. Female pigs, too, were brutally protective of their own kind, yet in their case the LDP frames this more negatively, like a kind of cruel hostility. For instance, when a domestic sow "has fawned, she is very ferocious and she fights for her own and for other piglets". ${ }^{74}$ In this sense, the domestic sow paralleled the ferocity of her undomesticated counterpart, the female boar:

The females of boars are very cruel. When they have farrowed, they bite and tear apart very harshly those who wish to do them [their litter] harm. ${ }^{75}$

Sows' maternal instincts made them prone to aggression, which—-though commendable from the point of view of their kin-would have presented a major inconvenience when slaughtering their piglets. Such hostility was ultimately also undesirable in domestic pigs: a hostile pig does not make for an easy meal.

\section{Bred for One Purpose}

This brings me to the final, and perhaps most crucial, signifier of porcinity: fatness. Fabre-Vassas (1997) remarks that the "pig's nature is always to grow, never to regress" (p. 60). This concern for pigs' fatness, either for breeding and/or for slaughter, is apparent in the $L D P$ :

The pig fattens in 15 days and especially when one has him starve for three days in the beginning when one wants to him grow fat .... Barley is very good meat for piglets and especially when they have to engender. ${ }^{76}$

pigs that are domesticated know their shelter and return there in the evening without herding; they sleep voluntarily when they are fat. ${ }^{77}$

In other words, a fat pig is a docile pig is a good pig. This, in turn, made it easier to slaughter the swine. Indeed, "when pigs are fat they are well-mannered" and well-suited

70 "il se co[m]bat/co[n]tre le lou et le het de son nat[ur]e car le/lou sove[n]t effois me[n]gust les faons/et po[ur] ce le senglier le co[m]bat co[n]t[re] luy aux/dens et aux ongles po[ur] deffe[n]dre les fe/melles et les fao[n]s co[mm]e dit Pli[ni]" (Corbechon 1480, fol. 331v).

71 "et q[ua]nt il vois les faons q[ue]/les vene[ur]s po[ur]suivent s'il ne peut fuir il/se met po[ur] eulx en p[er]il de mort" (Corbechon 1480, fol. 331v).

72 "Derechief au/cunes bestes sont de fier courage et/se co[m]bate[n]t voulentiers et p[ar] esp[eci]al q[ua]nt/elles sont en amours sicomme le porc" (Corbechon 1480, fol. 327v).

73 "les pors s'entrainent d'une moult gra[n]de/amour" (Corbechon 1485, fol. 264r); "les pors s'ent[r]ainie[n]t et co[n]/gnoissent la voix l'un de l'autre et/se l'un crie tous les aultres acoure[n]t/aluy et s'efforce[n]t de le delivrer a leur/pou[v]oir" (Corbechon 1480, fol. 355v).

74 "et q[ua]nt elle a faons elle/e[st] m[u]lt fiere et se co[m]bat po[ur] eulx et po[rce]les/aultres" (Corbechon 1480, fol. 358r).

75 “Les fe/melles des sengliers sont $\mathrm{m}[\mathrm{ul}] \mathrm{t}$ cruell[e]z/q[uan]t elles ont fao[n]s morde[n]t et depiece[n]t/m[ul]t cruelleme[n]t ceulx q[ui] mal le[ur] veule[n]t/faire" (Corbechon 1480, fol. 331v).

76 "Le porc engresse en $\mathrm{xv}$ jours et $\mathrm{p}$ [ar] es-/pecial q[ua]nt on le fait jeuner p[ar] trois/iours au co[m]me[n]cem[en]t q[ua]nt on le veult/engresser. ... L'orge est bo[n]ne via[n]de/aux porcz et p[ar] esp[eci]al q[ua]nt ils doive[n]t [ . . ]" (Corbechon 1480, fol. 355v). The scribe here abruptly ended the sentence and continued onto another topic, but I have been able to reconstruct the sentence via BnF fr. 218: "l'orge est moult bonne viande pour/les po[ur]ceaulx et par esp[eci]al qua[n]t ils doy-/vent engendrer" (Corbechon 1485, fol. 364v).

77 "les porcs q[ui] sont prives co-/gnoissent le hostel et y reto[u]rne[n]t au/soir sans mener dorme[n]t voule[n]-/tiers q[ua]nt ils sont gras" (Corbechon 1480 , fol. $355 \mathrm{v})$. 
to a hot bath (which made their veins more visible), during which blood would be drained

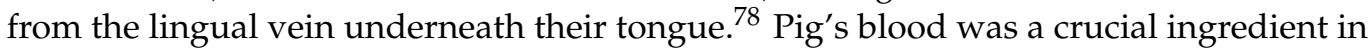
blood puddings, blood sausages, and similar recipes (Rogers 2012, p. 37; Jørgensen 2018, p. 228), and the mediaeval archaeological record indicates that piglets "were slaughtered as soon as they could yield sufficient meat" (Steel 2011, p. 180). ${ }^{79}$

For all its convenience and savour, domestic pork remained inferior to boar meat-a delicacy worth hunting for-because of two factors. Firstly, the boar "does not cease running after the females and because of this he is thus very lean", and secondly, boars lived "from the roots and grass and fruit of the trees" in their forests. ${ }^{80}$ Undomesticated pigs had a much more active lifestyle and a healthier diet than their domestic counterparts, who thrived by consuming all sorts of muck while wallowing in the dirt. To remedy this, domestic pigs were released once a year, shortly before they were slaughtered, as porcs de pannage ('pannage pigs') so they could feed on acorns, beech mast, rhizomes, and nuts. In fact, fattening up pigs for slaughter through pannage was so ingrained within the mediaeval agricultural cycle that it became "the standard calendar depiction" for the months of October, November, and December (Jørgensen 2013, p. 389). While pannage somewhat mitigated the dietary differences between domestic pigs and boars, it was not sufficient to improve the quality of domestic pig meat. Referring to Isaac Israeli ben Salomon's analysis of diet and the necessary conditions for nutritional meat, the LDP suggests that to achieve boar-like savouriness, domestic pigs had to mimic the boar's natural behaviour. ${ }^{81}$

The flesh of a boar is much drier and less cold than that of the domestic pig according to Isaac and that is why the boar moves more often and lives off very dry meats and in hotter air than the domestic pig, and because of this his head is tougher and his fat and flesh more delicious; and from this results that the domestic pig is hunted and chased around for a very long time when one wants to kill him, because through such movement his meat is rendered more tender and also of better taste. ${ }^{82}$

Swineherds set themselves the objective of reverse-engineering boar meat from domestic pig meat. Boars ran around incessantly because of their dry and hot flesh. The flesh of domestic pigs was allegedly moister and colder by nature. Directly changing this nature obviously did not lie within the power of humans. However, to those who subscribed to the notion that species is mutable, altering the pigs' behaviour could be an indirect method to adapt their physiognomy and render them more akin to boars. As domestic pigs were no active runners of their own volition, swineherds contrived a strategy to get them to run, chasing pigs around for an exceedingly long time in hopes of rendering their meat more tender. This process undoubtedly generated substantial stress in the suids right before their slaughter. The $L D P$, however, does not evoke any kind of awareness of the plight of these animals - the matter-of-factness of this description suggests that this was business as

78 “q[ua]nt les porcz sont gras les meurez/leur sont bo[n]nes et leur e[st] bon le bain/en eaue b[ie]n chaulde et le seignier/de la vai[n]e q[ui] e[st] soubz la langue" (Corbechon 1480, fol. 355v).

79 The people of Bavaria and Franconia held that consuming blood sausage offered protection from illnesses such as Saint Anthony's Fire (Fabre-Vassas 1997, p. 291).

80 "il ne cesse de cour/re apres les femelles et po[ur] ce e[st] il ado[n]c/m[u]lt maigre ... et la/vive[n]t des raci[n]es et des herbes et du fruit/des arbres" (Corbechon 1480, fol. 331v).

81 Isaac Israeli ben Salomon, a tenth-century Jewish physician and philosopher, wrote the Liber dietarum universalium and the Liber diaetarum particularium to which the LDP here refers (Bazell 1995, pp. 236-37).

82 "La char du senglier e[st] pl[us] seche et/plus froide q[ue] celle du porc prive co[mm]e/dit Ysaac et c'est po[ur] ce q[ue] le senglier se/meut pl[us] souve[n]t et vit de plus seches/via[n]des et en plus chault air q[ue] le porc/prive et po[ur] ce la teste en est pl[us] dur/et la char pl[us] delicieuse et de ce vie[n]t q[ue] le/ver p[ri]ve e[st] vene et chasse m[ul]t longueme[n]t/q[ua]nt on le veult tuer po[ur] ce q[ue] p[ar] tel mou-/vem[en]t la char en soit pl[us] te[n]dre et aus-/si de meille[ur] saveur" (Corbechon 1480, fol. 331v); "La chair du senglier/est plus seiche et moins froide q[ue] celle/du prive et se est par son mouveme[n]t/et aussi car il vit de plus seiches vi-/andes et en lieu plus chault q[ue] le porc/prive et pour ce sa chair en est plus dure/et sa gresse et sa chair plus delicieuse/et de ce vient que le ver prive est vene/et travaille moult longueme[n[t qua[n]t/on le veult tuer pour ce q[ue] par tel mou-/veme[n]t la chair en soit plus tendre et/de meilleur saveur" (Corbechon 1485, fol. 332r). 
usual, simply what had to be done so humans could enjoy a lean pork chop without the hassle of hunting and fighting boars.

In addition to its nutritional benefits, the fatness of pigs also played an important role in breeding more pigs (to keep the cycle going). In this regard, potential advantages of fattening the pig depended on the animal's gender. In the case of hogs (uncastrated male pigs), fattening them up was advantageous as "the uncastrated pig that is fat may mount at any time". ${ }^{83}$ Fat sows, on the other hand, were undesirable as they produced less milk to feed their sucklings, and "if sows eat many acorns, they abort [their pregnancy] like ewes do according to Aristotle". ${ }^{84}$ Failed pregnancies were to be avoided at all costs as the LDP indicates that the primary objective of keeping sows was that they could breed and raise more piglets. Paraphrasing Aristotle, the text for instance explains how variables such as time factor into the reproductive cycle of suids, while also tacitly prescribing the most effective way to acquire healthy and strong litters of piglets. ${ }^{85}$ Sows were known to resist male suitors unless if they were in heat, reportedly indicated by the lowering of their ears. ${ }^{86}$ Young sows which had farrowed at least once already apparently produced optimal litters. ${ }^{87}$ Chapter 97 briefly zooms in on sows an sich, paraphrasing Pliny the Elder's description that a sow could give birth twice a year, sometimes producing nine to twenty piglets in one farrow, in which case feeding all infants was impossible, leading the maternal sow to kill and consume all but her firstborn young. ${ }^{88}$ This 'savaging', as it is presently called, still occurs in pig husbandry, particularly in factories that use a so-called farrowing crate to contain the maternal sow and her young. Research on pig welfare (Špinka 2017) shows that savaging relates less to a sow's maternal quality or the quantity of her litter than to the poor and restrictive environment she is kept in (p. 81).

In these and other descriptions, the $L D P^{\prime}$ 's overall apparently matter-of-fact, passive voice is significant as it obscures the acting human subject, implying that it was no more than fact that porcine animals looked and behaved a certain way and that they were meant to be treated in a particular manner. The connection between pigs and gluttony-also common in late mediaeval French proverbs (Pastoureau 1989, p. 276) -is particularly insidious. ${ }^{89}$ Domestic male pigs were in life continuously constrained to eat voraciously so as to fatten quickly or to breed often, both of which were meant to ensure that there was no shortage of pigs for human consumption. In fables, sermons, woodcuts, heraldic imagery, et cetera, pigs were then vilified precisely for complying with the normative parameters that had been set by humans. The $L D P^{\prime}$ s recurrent invocation of rhetorics of authority, through quotation or paraphrase of respected classical, patristic, and mediaeval scholars, further highlighted that such traits were innately porcine and that human exploitation of pigs was just as natural. These two factors allow the $L D P$ to displace who is observing pigs and, troublingly, to obfuscate the extensive human machinations at play which sought to mould pigs into easily multipliable food. Additionally, the-arguably hypocritical-aversion to living pigs was highly convenient because it allowed humans to distance themselves from

83 "le ver/q[ui] e[st] gras peut saillir en tous te[m]ps/mais plus au matin q[u'] a aultre/heure" (Corbechon 1480, fol. 355v).

84 "et q[ua]nt/elle e[st] trop grasse elle a petit de lait.... D[er]e/chief les porz me[n]gue[n]t voulent[e]s/les glandz mais si les truies en/menguent $\mathrm{m}[\mathrm{u}] \mathrm{lt}$ elles avortisse[n]t ai[n]si co[mm]e font les brebis co[mm]e dit A[ristote]" (Corbechon 1480, fol. 355v).

85 "du porc dit/A[ristote] ou tiers livre q[ue] le masle sault/la femelle q[ua]nt il a viii mois et la/femelle fao[n]ne apres un an et ce q[ue]/le masle enge[n]dre ava[n]t q[u'i]l ait un/an e[st] n[a]ist foible" (Corbechon 1480, fol. 355v).

86 "q[ua]nt elle a g[ra]nt apetit au fait de/nat[ur]e elle ne laisse poi[n]t mo[n]ter sur/luy le masle iusques ata[n]t q[u'e]lle en/cli[n]e les ores" (Corbechon 1480, fol. 355v).

87 “De[re]chief il dit q[ue] la/truie porte la p[re]mie[re] fois plus petis/porceaulx q[u'] au ault[re]ffois et ... mieux vallent les po[r]ceaulx q[ui]/sont nes en h[i]ver q[ue] ceulx q[ui] so[n]t nez/en este et mieulx valent ceulx q[ui] so[n]t/nes ieune mere q[ue] de vieille" (Corbechon 1480, fol. 355v).

88 “elle fao[n]ne deux fois l'an et/a aucu[n]e ffois ix po[r]celes a un coup/mais elle ne les peut nourrir et les/me[n]gust aucu[n]e ffois mais q[ue] le $\mathrm{p}$ [re]mier/ne a q[u']elle do[n]ne la premiere mamelle/co[mme] dit Pli[ne]" (Corbechon 1480, fol. 358r); "Elle faonne/deux fois l'an et fait aucu[n]e ffois vingt/porcelles a une ffois mais elle ne/les peut nourrir et les me[n]ge ne/aucu[n]e ffois fors q[ue] le p[re]mier a qui/elle donne la premiere mamelle sico[mme]/dit Plinius" (Corbechon 1485, fol. 367v).

89 In a Hebrew story, Noah allows the devil to kill various nonhumans to render the vine fruitful. Humans who consumed the resulting wine then took on properties of the slaughtered nonhumans. Kearney (1991) observes that some mediaeval French towns were inspired by this story, naming their wines after different kinds of nonhumans depending on the strength of the wine. One of these wines was named after pigs because its strength could reportedly render one 'bloated as a hog' (p. 167). 
the living and breathing animals that they exploited, enabling the consumption of pork "without eliminating the obligation to give some of it away, the ultimate way of placing its blood at a distance" (Fabre-Vassas 1997, p. 5).

\section{Concluding Remarks}

The $L D P^{\prime}$ s configuration of porcinity consists of several pejoratively charged physiognomic and behavioural signs of spiritual baseness that a good Christian human was to eschew or overcome. Porcine animals were carnal, lascivious beasts with a predilection for earthly delights. This was apparent in the downward inclination of their face and the eagerness with which they consumed foul earthly matter, be it literally (muck, garbage, or excrement) or allegorically (sins of the flesh). Moreover, their short legs and bristly hides ensured that they were constantly mired in this foul material, something which they also seemed to relish wallowing in. This caused them to have a fetid smell, another unmistakeable sign of moral corruption. Additionally, porcine animals were imagined to be harsh and cruel beasts, difficult-if not impossible-to subjugate to human domestication. Their whimsical capacity for violence with lethal tusks evidenced an ambiguously perceived ferocity: as impressive in boars (epic foes) as it was despicable in domestic pigs (livestock/slaves). In either case, however, this ferocity had to be vanquished to affirm humankind's dominion over the natural world. Finally, porcine animals' fatness, a result of their omnivory-no matter how foul (excrement) or sacrosanct (human flesh)—rendered them the epitome of gluttony. The fulcrum of sin was the sow, who suckled all porcine animals-human or otherwise. Although these constructions of porcinity built on actual physical or behavioural features of pigs and other animals, it is important to emphasise that their pejorative connotations amount to little more than a narrative, projections that made certain species into at once more and less than what they actually were. The alignment of porcinity with gluttony and lechery is thus to be understood as an insidious form of ventriloquism that uses particular kinds of nonhuman bodies as vessels through which to articulate human underbelly (venter + loquī) sentiments, mired in disgust, an emotion that devaluates its object of attention while anxiously recoiling for fear of contamination.

Porcinity thus mediated the human-nonhuman divide, though not in an uplifting kind of way. ${ }^{90}$ As a result, humans and nonhuman species such as pigs, boars, hedgehogs, and porcupines could never be dissociated in absolute terms. Humans differed from pigs only by several degrees of physiognomic, behavioural, and spiritual separation, rather than an insurmountable difference. Christians, too, could 'slip' like other human pigs and become something porcine if they followed the example of the disgustingly delicious and deliciously disgusting pig. This is exemplified in Hieronymus Bosch's famous Garden of Earthly Delights, in which clerical corruption is represented by depicting a hellscape in which a sow wears a habit (Bosch 1500). While God had reportedly favoured the human species with a superior position in the hierarchy of earthly creatures, an individual human's ranking was therefore never entirely secure. The world was reportedly replete with beastly exempla—nonhuman animals, monstrous hybrids, degenerate humans-all of which demonstrated how susceptible one's exalted humanity was to pollution by straying from Christian civilisation and indulging in foul, sinful inclinations. Giving in to such unbecoming sins as lasciviousness or gluttony essentially meant un-becoming human, to regress into subhumanity. This devolution rhetoric policed the boundaries of what a proper Christian person was supposed to be, facilitating the stigmatisation and persecution of those who diverged from Christian normativities. Occasionally, Christians themselves were the target of satirical discourse that subverted their hegemony by drawing attention to their own porcine ways. For instance, Jews were not averse to turning the tables on Christians as pigs "frequently functioned as metaphors for enemies" like Rome, Christians,

90 This rather negative conclusion must also, as Steel (2011) rightfully points out, "be tempered by expecting that some humans who tarry with the abjected animal will emerge from their sojourn less committed to their humanity"; indeed, some of the $L D P^{\prime}$ s readers "might have been inspired to surrender the defense of [their] humanity and to abandon [themselves] to previously unthought possibilities" (p. 58). Thus understood, the abjection of the $L D P^{\prime}$ s entries provided both an opportunity to reinforce harmful notions of human purity and to think the human otherwise. 
pagans, and even "bad Jews" within Jewish tradition (Wiedl 2010, p. 347). Even outside mediaeval Christianity, porcinity thus constituted a field of tension between undiluted humanity and the irredeemable domestic pig, who gruntles contentedly as she gobbles up filth from the muck.

The everyday revulsion to the sordid and, at times, violent reality of cohabiting with pigs, combined with this profound fear of species slippage, largely accounts for the squalid reputation of pigs in the Late Middle Ages. Pigs' biological likeness and proximity to humankind arguably situated them in the uncanny valley, a perceptual twilight zone in which the human and nonhuman, life and death, animation and stasis, meet. The roboticist Masahiro Mori coined the term 'uncanny valley' to denote the inflection point at which the resemblance of a nonhuman to a human becomes sufficiently unsettling to incite an eery discomfort, a sense of repulsion, or even outright hostility in humans (Mori [1970] 2012, pp. 98-100). In this case, domestic pigs were too close for comfort, threatening to destabilise the untouchable integrity and exceptionalism of humankind's own place in the cosmic hierarchy. The disgust towards pigs and porcinity thus underscores the zero-sum thinking that is inherent to hierarchies. In a zero-sum game, each participant only stands to gain something if the other participants lose. Conversely, Christian humans can only take up a superior position if pigs, and porcine animals more generally, occupy an inferior position. The more unquestionably 'nonhuman' pigs were, the harder it was for humans to fall from their exalted position into the mire of porcine nonhumanity. The devaluating function of aversion in this sense arguably had a reassuring effect: no human could ever stoop that low.

Through the devaluating effect of discourses of porcinity, mediaeval Christians could justify their dominion over real porcine animals, allowing them to breed, shape, slaughter, exploit, and consume these species without compromising their conscience. Significantly, the $L D P$ is written in an apparently neutral tone of voice as though it describes no more than facts or divine directives. This denotes a pernicious kind of rhetoric that contrives to strip real animals of their agency and subjectivity. The $L D P$ suggests that porcine bodies are canvases for human normativities and that these nonhumans are merely reasonless beasts, to be moulded by and instrumentalised for Man's practical and didactive needs. This suggests a kind of species solipsism that frames pigs as mere figurants and plot devices on the stage of the only real protagonist that matters: humankind. Porcine nonhumans lives, their health, their reproductive organs, even the very hair on their skin: all of it was subsumed by an anthropocentric agenda that did not have these animals' best interest at heart—unless if that served human self-interest somehow. Indeed, although "many medieval works consider the slaughter, butchery, and consumption of animals... Virtually no medieval work pays any attention to the lives animals lose in becoming meat. Only anthropophagy, a subjectively violent assault on the objectively violent status quo, might inspire horror or obsessional appetites" (Steel 2011, p. 123). The absence of any kind of interest in the welfare of porcine nonhumans for their own sake, or gratitude and compassion for these species, further demonstrates this solipsism. This attitude was most likely not a late mediaeval idiosyncrasy and arguably built on many centuries-if not millennia-of interaction, cohabitation, and mutual domestication of Homo sapiens, Sus scrofa (domesticus), and other species. ${ }^{91}$ It is not my intention to dole out moral condemnation on how humans have historically treated other species as I am aware that nonhumans can be vital for human survival in subsistence societies. It is remarkable, however, that this importance rarely resulted in actual respect.

Though much has changed since the Late Middle Ages, this instrumentalist and objectifying pattern is currently still operative as today, "use value-whether an animal is primarily used as food, milk, eggs, or whatever-is the main way in which humans in the West classify animals" (DeMello 2012, p. 49). In fact, the present political economy

91 There are historical exceptions that arguably confirm the rule, such as Plutarch's exhortation: "let us at least be ashamed of our ill doing and resort to it only in reason. We shall eat flesh, but from hunger, not as a luxury. We shall kill an animal, but in pity and sorrow, not degrading or torturing it-which is the current practice in many cases" (Plutarch 1957, p. 565; Dombrowski 2014, p. 549). 
of "full-scale discursive and material exploitation" of nonhumans has only intensified this attitude to nonhuman life, utilising living nonhuman bodies for the industries of science, agriculture, fashion, healthcare, et cetera (Braidotti 2013b, pp. 70, 75)—often at such a distance from human consumers that nonhuman lives and deaths are rendered so anonymous as to seem insignificant, reduced to little more than a neat row of plastic-wrapped meat in a supermarket. ${ }^{92}$ A recent report by the Intergovernmental Science-Policy Platform on Biodiversity and Ecosystem Services (IPBES) forebodes a grim future if no significant transformations occur in humankind's devastating exploitation of the natural environment. However, they urge that it is not yet too late: "Nature can be conserved, restored and used sustainably while other global societal goals are simultaneously met through urgent and concerted efforts fostering transformative change" (Brondizio et al. 2019, pp. 10-19). The actions that are required to kickstart this transformative change will also require a shift in attitude towards non-exploitative, eco-centric relationalities with nonhuman species. Actualising this objective requires counter-hegemonic reconsiderations of our interspecies histories because human exceptionalism also entails a "historical and social structure of exploitation of other species" (Marchesini 2016b, p. 222). The historian's key function herein is to be a 'Remembrancer', one who reminds people of what they would have liked to forget (Burke 1997, p. 59). This necessitates adopting an anthropocritical approach, which questions the human signification of historical sources and seeks to expose the obscured, yet all too real, suffering of past animals at the hands of human instrumentalisation. While these animals cannot retroactively be saved, their squeals deserve to be heard.

Funding: This research received no external funding.

Institutional Review Board Statement: Not applicable.

Informed Consent Statement: Not applicable.

Data Availability Statement: All data used in this article are publicly available.

Acknowledgments: Part of this research was presented at the IMC Leeds in 2018; I thank the organisers and attendees for the fruitful conversations. This article is based on my master's dissertation, "Homo Imperfectus. Human Exceptionalism and the Prosecution of Pigs in Late Mediaeval France", which benefited from encouraging comments by Babette Hellemans (University of Groningen; The Netherlands) and Steven Vanden Broecke (University of Ghent; Belgium). I also wish to convey my thanks to Aurélie J. Debaene (University of Kent; United Kingdom) and, particularly, the editor of this special-topics issue and the anonymous peer reviewers for their generous suggestions on the initial version of this essay.

Conflicts of Interest: The author declares no conflict of interest.

\section{References}

Adorno, Theodor, and Max Horkheimer. 2002. Dialectic of Enlightenment. Philosophical Fragments. Edited by Gunzelin Schmid Noerr. Translated by Edmund Jephcott. Stanford: Stanford University Press. First published 1947.

Ambrose, Saint. 1961. Hexameron, Paradise, and Cain and Abel. Translated by John J. Savage. New York: Fathers of the Church.

Anglicus, Bartholomaeus. 1492. De Proprietatibus Rerum. Nuremberg: Anton Koberger.

Anthony of Padua Saint. 1856. Sinners are Compared to Hedgehogs. In Mediaeval Preachers and Mediaeval Preaching: A Series of Extracts. Edited by John Mason Neale. Translated by John Mason Neale. London: J.C. Mozley, pp. 246-47.

Augustine, Saint. 2008. The City of God, Books VIII-XVI. Edited by Grace Monahan and Gerald G. Walsh. Translated by Grace Monahan, and Gerald G. Walsh. Washington, DC: Catholic University of America Press.

Bal, Mieke. 1999. Quoting Caravaggio. Contemporary Art, Preposterous History. Chicago: The University of Chicago Press.

Baratay, Éric. 2012. Le point de vue animal. Une autre version de l'histoire. Paris: Le Seuil.

Saint Basil of Caesarea. 2003. On the Hexaemeron. In Saint Basil. Exegetic Homilies. Edited by Agnes C. Way. Translated by Agnes C. Way. Washington, DC: Catholic University of America Press, pp. 3-135.

Bayless, Martha. 2012. Sin and Filth in Medieval Culture. The Devil in the Latrine. London: Routledge.

92 A less obvious example than pig factory farming is how pigs are now genetically modified to produce organs that can be harvested for human xeno-transplantation experiments (Braidotti 2013b, p. 70). 
Bazell, Dianne M. 1995. De Esu Carnium: Arnald of Villanova's Defence of Carthusian Abstinence. In Actes de la I Trobada Internacional d'Estudis sobre Arnau de Vilanova. Edited by Josep Perarnau. Barcelona: Institut d'Estudis Catalans, vol. 2, pp. 227-48.

Bianciotto, Gabriel, ed. 1980. Bestiaires du Moyen Âge. Paris: Stock.

Bosch, Hieronymus. 1500. Garden of Earthly Delights. Oil on panel, $220 \times 389 \mathrm{~cm}$. Madrid: Museo Nacional del Prado.

Braidotti, Rosi. 2013a. Posthuman Humanities. European Educational Research Journal 12: 1-19. [CrossRef]

Braidotti, Rosi. 2013b. The Posthuman. Cambridge: Polity Press.

Briand, Julien. 2016. Réglementer la présence des animaux en ville. Le cas des villes champenoises à la fin du Moyen Âge. Société française d'histoire urbaine 3: 29-52. [CrossRef]

Brondizio, Eduardo, Josef Settele, Sandra Díaz, HienThu Ngo, Maximilien Guèze, John Agard, Almut Arneth, Patricia Balvanera, Kate Brauman, Stuart Butchart, and et al., eds. 2019. Summary for Policymakers of the Global Assessment Report on Biodiversity and Ecosystem Services of the Intergovernmental Science-Policy Platform on Biodiversity and Ecosystem Services. Bonn: IPBES secretariat. [CrossRef]

Brumberg-Chaumont, Julie. 2017. Homo Logicus, la logique aux limites de l'humanité: Approches historiques, anthropologiques et philosophiques. Paper presented at Laboratoire d'Excellence HaStec, Paris, France, October 26.

Brumberg-Chaumont, Julie. 2018. Les usages de la logique au Moyen Âge latin: L'essor d'une norme sociale et intellectuelle. Paper presented at the Collège de France, Paris, France, May 15.

Brumberg-Chaumont, Julie. 2021. The Rise of Logical Skills and the 13th Century Origins of the Logical Man. In Logical Skills. Social-Historical Perspectives. Edited by Julie Brumberg-Chaumont and Claude Rosental. Berlin: Springer, pp. 91-120, in press.

Buren, Raymond. 1987. La cuisine du porc. In Le cochon. Histoire, symbolique et cuisine. Edited by Jacques Verroust. Paris: Sang de la Terre, pp. 91-176.

Burke, Peter. 1997. History as Social Memory. In Varieties of Cultural History. Ithaca: Cornell University Press, pp. 43-59.

Byrne, Donal. 1981. Rex imago Dei: Charles V of France and the Livre des propriétés des choses. Journal of Medieval History 7: 97-113. [CrossRef]

Calame, Claude, and Mondher Kilani. 1998. Introduction to La fabrication de l'humain dans les cultures et en anthropologie. Edited by Claude Calame and Mondher Kilani. Lausanne: Université de Lausanne, pp. 5-14.

Chasseguet-Smirgel, Janine. 2011. Le corps comme miroir du monde. Paris: Presses Universitaires de France.

Cohen, Esther. 1986. Law, Folklore and Animal Lore. Past and Present 110: 6-37. [CrossRef]

Cohen, Esther. 1992. The Crossroads of Justice. Law and Culture in Late Medieval France. Leiden: Brill.

Cohen, Esther. 1994. Animals in Medieval Perceptions: The Image of the Ubiquitous Other. In Animals and Human Society: Changing Perspectives. Edited by Aubrey Manning and James Serpell. London: Routledge, pp. 59-89.

Cohen, Jeffrey Jerome. 2008. Inventing with Animals in the Middle Ages. In Engaging with Nature: Essays on the Natural World in Medieval and Early Modern Europe. Edited by Barbara Ann Hanawalt and Lisa J. Kiser. Notre Dame: University of Notre Dame Press, pp. 39-62.

Cohen, Simona. 2008. Animals as Disguised Symbols in Renaissance Art. Leiden: Brill. [CrossRef]

Comet, Georges. 1997. Technology and Agricultural Expansion in the Middle Ages: The Example of France North of the Loir. In Medieval Farming and Technology: The Impact of Agricultural Change in Northwest Europe. Edited by Grenville Astill and John Langdon. Leiden: Brill, pp. 11-40.

Constable, Olivia Remie. 2013. Food and Meaning: Christian Understandings of Muslim Food and Food Ways in Spain, 1250-1550. Viator 44: 199-236. [CrossRef]

Corbechon, Jean. 1415. Le livre des propriétés des choses. MS 251. Cambridge: Fitzwilliam.

Corbechon, Jean. 1480. Le livre des propriétés des choses. MS fr. 9140. Paris: BnF, Available online: https://gallica.bnf.fr/ark: /12148/btv1b10532588f (accessed on 23 November 2018).

Corbechon, Jean. 1485. Le livre des propriétés des choses. MS fr. 218. Paris: BnF, Available online: https://gallica.bnf.fr/ark:/12148/btv1 b100225036 (accessed on 12 June 2020).

Crane, Susan, ed. 2010. Symposium: Animal Methodologies. New Medieval Literatures 12: 117-77.

Crane, Susan. 2013. Animal Encounters: Contacts and Concepts in Medieval Britain. Philadelphia: University of Pennsylvania Press.

Darwin, Charles. 1871. The Descent of Man, and Selection in Relation to Sex. London: John Murray, vol. 1.

Daston, Lorraine, and Katharine Park. 1998. Wonders and the Order of Nature. New York: Zone Books.

De Vaan, Michiel. 2008. Etymological Dictionary of Latin and the other Italic Languages. Leiden: Brill.

Deleuze, Gilles, and Félix Guattari. 1994. A Thousand Plateaus. Capitalism and Schizophrenia. Translated by Brian Massumi. Minneapolis: University of Minnesota Press. First published 1980.

DeMello, Margo. 2012. Animals and Society. An Introduction to Human-Animal Studies. New York: Columbia University Press.

Descamps, Benôit. 2014. 'Chairs loyales et déloyales': Les animaux de boucherie dans les règlements de métiers urbains à la fin du Moyen Âge. In L'humain et l'animal dans la France médiévale (XIIe -XVe s.). Edited by Irène Fabry-Tehranchi and Anna Russakoff. Amsterdam: Rodopi, pp. 193-208. [CrossRef]

Dines, Ilya. 2008. The Textual and Pictorial Metamorphoses of the Animal Called Chyrogrillius. In Science Translated: Latin and Vernacular Translations of Scientific Treatises in Medieval Europe. Edited by Michèle Goyens, Pieter De Leemans and An Smets. Leuven: Leuven University Press, pp. 71-89. 
Dittmar, Pierre-Olivier. 2013. Lapsus figurae. Notes sur l'erreur iconographique. In Quand l'image relit le texte. Regards croisés sur les manuscrits médiévaux. Edited by Sandrine Hériché-Pradeau and Maud Perez-Simon. Paris: Presses de la Sorbonne Nouvelle, pp. 319-35.

Dittmar, Pierre-Olivier, Chloé Maillet, and Astrée Questiaux. 2011. La chèvre ou la femme. Parentés de lait entre animaux et humains au Moyen Âge. Images Re-vues 9: 1-42.

Dombrowski, Daniel A. 2014. Philosophical Vegetarianism and Animal Entitlements. In The Oxford Handbook of Animals in Classical Thought and Life. Edited by Gordon Campbell. Oxford: Oxford University Press, pp. 535-55. [CrossRef]

Douglas, Mary. 2001. Purity and Danger: An Analysis of Concepts of Pollution and Taboo. London: Routledge. First published 1966.

Dubois, Adrien. 2017. L'exécution de la truie de Falaise en 1387. HAL Archive ouverte en Sciences de l'Homme et de la Société, 1-14. Available online: https:/ /halshs.archives-ouvertes.fr/halshs-01619964 (accessed on 15 July 2020).

Ducos, Joëlle. 2014. Une encyclopédie européenne à la fin du Moyen Âge. In Encyclopédie médiévale et langues européennes: Réception et diffusion du De proprietatibus rerum de Barthélémy l'Anglais dans les langues vernaculaires. Edited by Joëlle Ducos. Paris: Honoré Champion, pp. 7-12.

Dursteler, Eric. 2020. The "Abominable Pig" and the "Mother of All Vices": Pork, Wine, and the Culinary Clash of Civilizations in the Early Modern Mediterranean. In Insatiable Appetite: Food as Cultural Signifier in the Middle East and Beyond. Edited by Kirill Dmitriev, Julia Hauser and Bilal Orfali. Leiden: Brill, pp. 214-41.

Eggert, Elmar. 2014. Les traductions en espagnol du De proprietatibus rerum de Bartholomaeus Anglicus. In Encyclopédie médiévale et langues européennes: Réception et diffusion du De proprietatibus rerum de Barthélémy l'Anglais dans les langues vernaculaires. Edited by Joëlle Ducos. Paris: Honoré Champion, pp. 259-77.

Elliot, Andrew B. 2017. Medievalism, Politics and Mass Media: Appropriating the Middle Ages in the Twenty-First Century. Woodbridge: Boydell \& Brewer.

Enders, Jody. 2002. Homicidal Pigs and the Antisemitic Imagination. Exemplaria 14: 201-38. [CrossRef]

Epley, Nicholas, Adam Waytz, and John Terrence Cacioppo. 2007. On Seeing Human: A Three-Factor Theory of Anthropomorphism. Psychological Review 114: 864-86. [CrossRef]

Epley, Nicholas, Adam Waytz, and John Terrence Cacioppo. 2010. Who Sees Human? The Stability and Importance of Individual Differences in Anthropomorphism. Perspectives on Psychological Science 5: 219-32.

Erwin, Bonnie. 2018. Zöopedagogies: Creatures as Teachers in Middle English Romance. New York: Routledge.

Fabre-Vassas, Claudine. 1997. The Singular Beast. Jews, Christians, and the Pig. Translated by Carol Volk. New York: Columbia University Press.

Flores, Nona C., ed. 1996. Animals in the Middle Ages. London: Routledge.

Frantz, Laurent A. F., Joshua G. Schraiber, Ole Madsen, Hendrik-Jan Megens, Alex Cagan, Mirte Bosse, Yogesh Paudel, Richard Crooijmans, Greger Larson, and Martien Groenen. 2015. Evidence of Long-Term Gene Flow and Selection During Domestication from Analyses of Eurasian Wild and Domestic Pig Genomes. Nature Genetics 47: 1141-48. [CrossRef] [PubMed]

Friedland, Paul. 2012. Seeing Justice Done: The Age of Spectacular Capital Punishment in France. New York: Oxford University Press.

Geertz, Clifford. 1973. The Impact of the Concept of Culture on the Concept of Man. In The Interpretation of Cultures. Selected Essays. New York: Basic Books, pp. 33-54. First published 1966.

Geltner, Guy. 2019. Roads to Health: Infrastructure and Urban Wellbeing in Later Medieval Italy. Philadelphia: University of Pennsylvania Press.

Goehring, Margaret. 2013. Space, Place and Ornament: The Function of Landscape in Medieval Manuscript Illumination. Turnhout: Brepols.

Goodrich, Peter, and Kristen Figg, eds. 2013. Medieval Pets. Special issue of Enarratio 18: 1-155.

Grene, Marjorie. 1974. People and Other Animals. In The Understanding of Nature. Essays in the Philosophy of Biology. Dordrecht: Springer, pp. 346-60.

Harris, Nigel. 2020. The Thirteenth-Century Animal Turn: Medieval and Twenty-First-Century Perspectives. Cham: Palgrave Macmillan. [CrossRef]

Hassig, Debra. 1999. Sex in the Bestiaries. In The Mark of The Beast. The Medieval Bestiary in Art, Life, and Literature. Edited by Debra Hassig. New York: Routledge, pp. 71-97.

Heng, Geraldine. 2018. The Invention of Race in the European Middle Ages. Cambridge: Cambridge University Press.

Hole, Jennifer. 2016. Economic Ethics in Late Medieval England, 1300-1500. Cham: Palgrave Macmillan. [CrossRef]

Holsinger, Bruce. 2009. Of Pigs and Parchment: Medieval Studies and the Coming of the Animal. PMLA 124: 616-23. [CrossRef]

Jones, Malcolm. 1991. Folklore Motifs in Late Medieval Art III: Erotic Animal Imagery. Folklore 102: 192-219. [CrossRef]

Jørgensen, Dolly. 2013. Pigs and Pollards: Medieval Insights for UK Wood Pasture Restoration. Sustainability 5: 387-99. [CrossRef]

Jørgensen, Dolly. 2018. Blood on the Butcher's Knife: Images of Pig Slaughter in Late Medieval Illustrated Calendars. In Blood Matters: Studies in European Literature and Thought, 1400-1700. Edited by Bonnie L. Johnson and Eleanor Decamp. Philadelphia: University of Pennsylvania Press, pp. 224-37. [CrossRef]

Kay, Sarah. 2017. Animal Skins and the Reading Self in Medieval Latin and French Bestiaries. Chicago: University of Chicago Press. [CrossRef]

Kearney, Milo. 1991. The Role of Swine Symbolism in Medieval Culture: Blanc Sanglier. Lewiston: E. Mellen Press.

Keen, Elizabeth. 2007. The Journey of a Book. Bartholomew the Englishman and the Properties of Things. Canberra: ANU E Press.

Kreiner, Jamie. 2017. Pigs in the Flesh and Fisc: An Early Medieval Ecology. Past and Present 236: 3-42. [CrossRef] 
Kristeva, Julia. 1982. Powers of Horror, An Essay on Abjection. Translated by Leon S. Roudiez. New York: Colombia University Press. Lipton, Sara. 1999. Images of Intolerance: The Representation of Jews and Judaism in the Bible Moralisée. Berkeley: University of California Press.

Liu, Jiangang, Jun Li, Lu Feng, Ling Li, Jie Tian, and Kang Le. 2014. Seeing Jesus in Toast: Neural and Behavioral Correlates of Face Pareidolia. Cortex 53: 60-77. [CrossRef] [PubMed]

Lloyd, Geoffrey Ernest Richard. 2012. Humanity between gods and beasts? In Being, Humanity, and Understanding. Oxford: Oxford University Press. [CrossRef]

Lutwyche, Richard. 2019. The Pig. A Natural History. Princeton: Princeton University Press.

MacGregor, Lesley B. 2019. Criminalising Animals in Medieval France: Insights from Records of Executions. Open Library of Humanities 5: 1-20. [CrossRef]

Malter, Henry. 1912. Personifications of Soul and Body. A Study in Judaeo-Arabic Literature. The Jewish Quarterly Review 2: 453-79. [CrossRef]

Marchesini, Roberto. 2016a. Nonhuman Alterities. Translated by Elena Past. Angelaki 21: 161-72. [CrossRef]

Marchesini, Roberto. 2016b. Posthuman Antispeciesism. Angelaki 21: 217-33. [CrossRef]

McCracken, Peggy. 2017. In the Skin of a Beast: Sovereignty and Animality in Medieval France. Chicago: University of Chicago Press.

Meyer, Helmut. 2006. Wie sahen Schweine im Mittelalter aus? Deutsche tierärztliche Wochenschrift 113: 15-23. [PubMed]

Miller, William. 1997. The Anatomy of Disgust. Cambridge: Harvard University Press.

Mitchell, John Allan. 2014. Becoming Human: The Matter of the Medieval Child. Minneapolis: University of Minnesota Press.

Mittman, Asa S. 2003. Headless Men and Hungry Monsters. Paper presented at the Sarum Seminar, Stanford, CA, USA, March 13.

Montanari, Franco. 2015. The Brill Dictionary of Ancient Greek. Leiden: Brill.

Mori, Masahiro. 2012. The Uncanny Valley [From the Field]. IEEE Robotics and Automation Magazine 19: 98-100. First published 1970. [CrossRef]

N.N. 1438. Horae ad usum romanum. MS lat. 1156B. Paris: BnF, Available online: https:/ /gallica.bnf.fr/ark:/12148/btv1b52502614h (accessed on 28 July 2020).

Newmyer, Stephen T. 2017. Human-Animal Interactions in Plutarch as Commentary on Human Moral Failings. In Interactions between Animals and Humans in Graeco-Roman Antiquity. Edited by Thorsten Fögen and Edmund Thomas. Berlin: Walter de Gruyter, pp. 233-52. [CrossRef]

Oelze, Anselm. 2018. Animal Rationality: Later Medieval Theories 1250-1350. Leiden: Brill. [CrossRef]

Pareles, Mo. 2015. Men as Meat: Exploiting Jewish Law in Alfric's Translation of Maccabees. Exemplaria 27: 187-204. [CrossRef]

Pareles, Mo. 2019. Always/Never. Jewish-Porcine Conversion in the Middle English Children of the Oven Miracle. Philological Quarterly 98: 221-42.

Parker, Patricia. 1992. Preposterous Events. Shakespeare Quarterly 43: 186-213. [CrossRef]

Pastoureau, Michel. 1987a. Le porc medieval. In Le cochon. Histoire, symbolique et cuisine. Edited by Jacques Verroust. Paris: Sang de la Terre, pp. 17-26.

Pastoureau, Michel. 1987b. Le porc dans les religions monothéistes. In Le cochon. Histoire, symbolique et cuisine. Edited by Jacques Verroust. Paris: Sang de la Terre, pp. 49-56.

Pastoureau, Michel. 1989. Couleurs, images, symboles: Études d'histoire et d'anthropologie. Paris: Le Léopard d'Or.

Pastoureau, Michel. 1993. Les extravagants procès d'animaux. Histoire. Société d'éditions Scientifiques 172: 16-23.

Pastoureau, Michel. 1999. L'animal et l'historien du Moyen Âge. In L'animal exemplaire au Moyen Âge, Ve-XVe siècles. Edited by Jacques Berlioz and Marie Anne Polo de Beaulieu. Rennes: Presses Universitaires de Rennes, pp. 13-26.

Pastoureau, Michel. 2000. Une justice exemplaire: Les procès faits aux animaux (XIIIe-XVIe siècle). In Les rites de la justice. Gestes et rituels judiciaires au Moyen Âge occidental. Edited by Claude Gauvard and Robert Jacob. Paris: Éditions Le Léopard d'Or, pp. 173-200.

Pastoureau, Michel. 2011a. The Bear: History of a Fallen King. Translated by George Holoch. Cambridge: Harvard University Press.

Pastoureau, Michel. 2011b. Bestiaires du Moyen Âge. Paris: Seuil.

Pastoureau, Michel. 2012. Symbolique médiévale et moderne. Annuaire de l'École pratique des hautes études (EPHE), Section des sciences historiques et philologiques 143: 198-206. [CrossRef]

Philips, Sarah. 2007. The Pig in Medieval Iconography. In Pigs and Humans: 10,000 Years of Interaction. Edited by Umberto Albarella, Keith Dobney, Anton Ervynck and Peter Rowley-Conwy. Oxford: Oxford University Press, pp. 373-87.

Pinkster, Harm, ed. 2014. Woordenboek Latijn-Nederlands, 6th ed. Amsterdam: Amsterdam University Press.

Plotinus. 1967. Ennead, Volume III. Translated by Arthur Hilary Armstrong. London: Heinemann.

Pluskowski, Aleksander, ed. 2007. Breaking and Shaping Beastly Bodies: Animals as Material Culture in the Middle Ages. Oxford: Oxbow Books.

Plutarch. 1957. On the Eating of Flesh. In Plutarch's Moralia. Translated by William C. Helmbold. Cambridge: Harvard University Press, vol. 12, pp. 537-79.

Polo, Marco. 1412. Livre des merveilles. MS fr. 2810. Paris: BnF, Available online: https://gallica.bnf.fr/ark:/12148/btv1b52000858n (accessed on 27 July 2020). 
Prüfer, Kay, Kasper Munch, Ines Hellmann, Keiko Akagi, Jason R. Miller, Brian Walenz, Sergey Koren, Granger Sutton, Chinnappa Kodira, Roger Winer, and et al. 2021. The Bonobo Genome Compared with the Chimpanzee and Human Genomes. Nature 486: 527-31. [CrossRef] [PubMed]

Remotti, Francesco. 1998. Thèses pour un perspective anthropopoiétique. In La fabrication de l'humain dans les cultures et en anthropologie. Edited by Claude Calame and Mondher Kilani. Lausanne: Université de Lausanne, pp. 15-32.

Ribémont, Bernard. 1999. Le livre des propriétés des choses: Une encyclopédie au XIVe siècle. Paris: Stock.

Richard, Olivier. 2015. Le jeu des aveugles et du cochon. Rite, handicap et société urbaine à la fin du Moyen Âge. Revue historique 317: 525-56. [CrossRef]

Ritvo, Harriet. 2007. On the Animal Turn. Daedalus 136: 118-22. [CrossRef]

Rivera, Annamaria. 1998. La construction de la nature et de la culture par la relation homme-animal. In La fabrication de l'humain dans les cultures et en anthropologie. Edited by Claude Calame and Mondher Kilani. Lausanne: Université de Lausanne, pp. 49-72.

Rogers, Katharine Munzer. 2012. Pork: A Global History. London: Reaktion Books.

Rudd, Gillian, ed. 2012. Colloquium: Animalia. Article cluster in Studies in the Age of Chaucer 34: 309-58.

Ryan, Maurice. 2019. Creating Judas Iscariot: Critical Questions for Presenting the Betrayer of Jesus. Journal of Religious Education 67: 223-37. [CrossRef]

Salisbury, Joyce E. 2011. The Beast Within: Animals in the Middle Ages, 2nd ed. London: Routledge. First published 1994.

Schouwink, Wilfried. 1984. The Sow Salaura and her Relatives in Medieval Literature and Art. In Epopée animale, fable, fabliau: Actes du IVe Colloque de la Société Internationale Renardienne, Evreux, 7-11 Septembre 1981. Edited by Gabriel Bianciotto and Michel Salvat. Paris: Presses Universitaires de France, pp. 509-24.

Špinka, Marek. 2017. Advances in Pig Welfare. Kent: Elsevier Science.

Steel, Karl. 2011. How to Make a Human. Animals and Violence in the Middle Ages. Columbus: Ohio State University Press.

Steel, Karl. 2019. How Not to Make a Human: Pets, Feral Children, Worms, Sky Burial, Oysters. Minneapolis: University of Minneapolis Press.

Steel, Karl, and Peggy McCracken, eds. 2011. The Animal Turn. Special issue of Postmedieval 2: 1-114.

Strickland, Debra. 2007. The Jews, Leviticus, and the Unclean in Medieval English Bestiaries. In Beyond the Yellow Badge: Anti-Judaism and Antisemitism in Medieval and Early Modern Visual Culture. Edited by Mitchell B. Merback. Leiden: Brill, pp. 203-32. [CrossRef]

Taylor, Anna. 2018. Where Are the Wild Things? Animals in Western Medieval European History. History Compass 16: 1-12. [CrossRef]

Thiébaux, Marcelle. 1969. The Mouth of the Boar as a Symbol in Medieval Literature. Romance Philology 22: 281-99.

Thomas, Keith. 1983. Man and the Natural World: Changing Attitudes in England, 1500-1800. London: Allen Lane.

Thompson, Cassidy Devon. 2018. Splitting Hairs: The Creation and Dissolution of Boundaries in Thirteenth-Century French Literature. Ph.D. thesis, Washington University in St. Louis, St. Louis, MO, USA.

Toivanen, Juhana. 2016. Beasts, Human Beings, or Gods? Human Subjectivity in Medieval Political Philosophy. In Subjectivity and Selfhood in Medieval and Early Modern Philosophy. Edited by Jari Kaukua and Tomas Ekenberg. Cham: Springer, pp. 181-97. [CrossRef]

Trevisa, John. 2019. On the Properties of Things: John Trevisa's Translation of Bartholomaeus Anglicus' De proprietatibus rerum. Edited by M. C. Seymour. Oxford: Clarendon Press, vol. 2. First published 1975.

Van den Abeele, Baudouin, Heinz Meyer, and Bernard Ribémont. 1999. Éditer l'encyclopédie de Barthélemy l'Anglais. Cahiers de recherches médiévales 6: 7-18. [CrossRef]

Van Es, Margaretha. 2020. Roasting a Pig in Front of a Mosque: How Pork Matters in Pegida's Anti-Islam Protest in Eindhoven. Religions 11: 359. [CrossRef]

Van Molle, Leen. 2012. Inleiding: Een Geschiedenis van Mensen en (Andere) Dieren. Tijdschrift voor Geschiedenis 125: 465-75. [CrossRef]

Van Uytven, Raymond. 2003. De Papegaai van de Paus. Mens en Dier in de Middeleeuwen. Leuven: Waanders Uitgevers.

Veysseyre, Géraldine. 2008. Le Livre des Propriétés des Choses de Jean Corbechon (livre VI) ou la vulgarisation d'une encyclopédie latine. In Science Translated: Latin and Vernacular Translations of Scientific Treatises in Medieval Europe. Edited by Michèle Goyens, Pieter De Leemans and An Smets. Leuven: Leuven University Press, pp. 331-59.

Warner, Marina. 1997. The Enchantments of Circe. Raritan: A Quarterly Review 17: 1-23.

Warren, Michael J. 2018. Birds in Medieval English Poetry: Metaphors, Realities, Transformations. Woodbridge: Boydell \& Brewer. [CrossRef]

Waterson, Robert, Eric Lander, and Richard K. Wilson. 2005. Initial Sequence of the Chimpanzee Genome and Comparison with the Human Genome. Nature 437: 69-87. [CrossRef]

Wei, Ian P. 2020. Thinking About Animals in Thirteenth-Century Paris: Theologians on the Boundary between Humans and Animals. Cambridge: Cambridge University Press. [CrossRef]

Wheatley, Edward. 2002. "Blind" Jews and Blind Christians; Metaphorics of Marginalization in Medieval Europe. Exemplaria 14: 351-82. [CrossRef]

Wiedl, Birgit. 2010. Laughing at the Beast: The Judensau: Anti-Jewish Propaganda and Humor from the Middle Ages to the Early Modern Period. In Laughter in the Middle Ages and Early Modern Times. Epistemology of a Fundamental Human Behavior, Its Meaning, and Consequences. Edited by Albrecht Classen. Berlin: De Gruyter, pp. 325-64.

Wildberger, Jula. 2008. Beast or God?-The Intermediate Status of Humans and the Physical Basis of the Stoic Scala Naturae. In Mensch und Tier in der Antike. Edited by Annetta Alexandridis, Lorenz Winkler-Horacek and Markus Wild. Wiesbaden: Reichert-Verlag, pp. $47-70$.

Wilkins, John S. 2009. Species: A History of the Idea. Berkeley: University of California Press. 
Williams, David. 1996. Deformed Discourse: The Function of the Monster in Mediaeval Thought and Literature. Montreal: McGill-Queen's University Press.

Wolfe, Cary. 2003. Introduction to Zoontologies. The Question of the Animal. Edited by Cary Wolfe. Minneapolis: University of Minneapolis Press, pp. ix-xxiii.

Yerkes, Royden Keith. 1923. The Unclean Animals of Leviticus 11 and Deuteronomy 14. The Jewish Quarterly Review 14: 1-29. [CrossRef] 